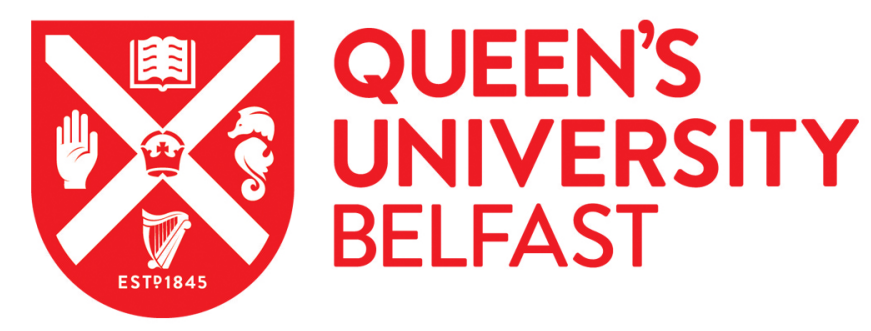

\title{
Quantification of groundwater storage heterogeneity in weathered/fractured basement rock aquifers using electrical resistivity tomography: sensitivity and uncertainty associated with petrophysical
} modelling

Mézquita González, J. A., Comte, J. C., Legchenko, A., Ofterdinger, U., \& Healy, D. (2020). Quantification of groundwater storage heterogeneity in weathered/fractured basement rock aquifers using electrical resistivity tomography: sensitivity and uncertainty associated with petrophysical modelling. Journal of Hydrology, [125637]. https://doi.org/10.1016/j.jhydrol.2020.125637

Published in:

Journal of Hydrology

Document Version:

Peer reviewed version

Queen's University Belfast - Research Portal:

Link to publication record in Queen's University Belfast Research Portal

Publisher rights

Copyright 2020 Elsevier.

This manuscript is distributed under a Creative Commons Attribution-NonCommercial-NoDerivs License

(https://creativecommons.org/licenses/by-nc-nd/4.0/), which permits distribution and reproduction for non-commercial purposes, provided the author and source are cited.

\section{General rights}

Copyright for the publications made accessible via the Queen's University Belfast Research Portal is retained by the author(s) and / or other copyright owners and it is a condition of accessing these publications that users recognise and abide by the legal requirements associated with these rights.

Take down policy

The Research Portal is Queen's institutional repository that provides access to Queen's research output. Every effort has been made to ensure that content in the Research Portal does not infringe any person's rights, or applicable UK laws. If you discover content in the Research Portal that you believe breaches copyright or violates any law, please contact openaccess@qub.ac.uk. 
1 Quantification of groundwater storage heterogeneity in weathered/fractured basement

2 rock aquifers using electrical resistivity tomography: sensitivity and uncertainty associated with petrophysical modelling

4 Jesús Alberto Mézquita González ${ }^{1 *}$, Jean-Christophe Comte ${ }^{1}$, Anatoly Legchenko ${ }^{2}$, Ulrich

5 Ofterdinger ${ }^{3}$, David Healy ${ }^{1}$

$6 \quad{ }^{1}$ University of Aberdeen, School of Geosciences, UK

$7 \quad{ }^{2}$ Univ. of Grenoble Alps, Institute of Research for Development, IGE, Grenoble, France

$8 \quad{ }^{3}$ Queen's University Belfast, Northern Ireland, UK

9 *Corresponding author: J. A. Mézquita González, School of Geosciences, University of Aberdeen, 10 Aberdeen, AB24 3UF. E-mail: j.mezquita@abdn.ac.uk

Abstract: Quantifying groundwater storage in weathered/fractured basement rock aquifers can be challenging owing to both their high degree of heterogeneity and their overall low storage capacity. Therefore, in these aquifers, the use of direct borehole hydraulic data is usually insufficient. Here we assessed the popular method of electrical resistivity tomography (ERT), combined with borehole data and including associated uncertainties, to resolve the spatial variability of groundwater storage properties at high resolution within a fractured mica schist aquifer in Ireland. Porosity distributions across both the saturated and unsaturated zones were calculated from two-dimensional (2D) ERT resistivities using two standard petrophysical models, Archie and Waxman \& Smits (WS), the latter accounting for the influence of clay minerals on resistivity data. Our results demonstrated the importance of the hydrogeological conceptual constraints provided by ERT when parametrizing the 2D petrophysical models from borehole point data. They also confirmed the importance of accounting for clay minerals (the products of bedrock weathering processes) in the WS model, whereas predictions from Archie's model produced unrealistically high porosity values of over an order of magnitude higher than the WS model. The WS model predicted porosities decreasing exponentially 
with depth, with values ranging from a few $\%$ in the shallowest, most-weathered part of the bedrock

27

(upper $5 \mathrm{~m}$ on average) and deep fractured zones (to about $20 \mathrm{~m}$ deep), to less than $1 \%$ in the underlying fissured aquifer, and possibly down another order of magnitude in the deep massive bedrock. WS-derived porosities were in agreement with independent vertical water content profiles derived from magnetic resonance sounding (MRS), as well as point storativity values estimated from borehole hydraulic testing at the study site, with particularly good matches in the upper weathered/fractured bedrock and deeply weathered/fractured zones associated with regional faults. Detailed comparison suggested that WS provides an upper-bound estimate of groundwater storage in this environment. In the deep massive, un-weathered, and poorly fractured bedrock, however, discrepancies between groundwater storage estimate obtained from the three methods (ERT, MRS, and hydraulic) prevented reliable storage quantification, owing to the methods' inherent technical limitations in such low porosity rocks. Our results demonstrated the suitability of resistivity tomography to quantify groundwater storage heterogeneity in weathered/fractured basement rock aquifers at high resolution and with reasonable overall uncertainty given the relative high uncertainties in petrophysical parameters at the kilometric scale. The results are promising for better characterization of groundwater storage variations in these hydrogeological systems, which are crucial to predict their response to climate variability and human exploitation.

Keywords: Hydrogeophysics; Hard rock aquifer; Petrophysics; Clays; Porosity; Storativity. 


\section{Introduction}

52

More than $90 \%$ of the total liquid fresh water is groundwater (Gleick, 1993) with a fraction of this water being stored in weathered/fractured basement rocks. Basement rock aquifers, including igneous and metamorphic rocks, are devoid of primary porosity and groundwater flow and storage take place through fractures and secondary porosity created by weathering processes. They are also often referred to as hard rock aquifers (Lachassagne et al., 2011). Some authors however also included under the definition of hard rock aquifers cemented sedimentary rocks (which can exhibit primary porosity) and hard carbonate rocks (which can also exhibit primary porosity and karstification) because of their similarly poor drillability, but these are not considered here. Basement, hard rock aquifers cover a fifth of the Earth's land surface (Singhal, 2008) and locally constitute socioeconomically and ecologically important water resources. The distribution and overall volume of water contained in these reservoirs are the least known primarily because of their high degree of heterogeneity and overall low productivity (Comte et al., 2012a). It is however acknowledged that most of groundwater flow and storage take place at a relatively shallow depth within the most weathered/fractured bedrock (Abdulaziz et al., 2012; Kumar et al., 2016). Such shallow depths of interest (tens of meters) make near-surface geophysical techniques suitable to characterize and understand weathered/fractured basement rock aquifers (Day-Lewis et al., 2017).

Until recently, the difficulties to locate and extract water from basement rock aquifers implied that they have been largely disregarded for water supply outside local rural use (MacDonald and Davies, 2000; Singhal, 2008). However, as a source more resilient than surface water to the predicted impact of climate change, basement rock aquifers, similarly to better known, more productive regional aquifer system, could play a strategic role in sustaining local drinking water supplies in an adaptation to predicted long-term climate change trends and short-term extreme drought events (Taylor et al., 2013). Therefore, new developments in basement rock aquifers characterization and sustainable exploitation are key for water security in the near future.

Understanding the function of weathered/fractured hard rock groundwater systems requires a good characterization of the complex geology, including structural heterogeneity such as fracture systems 
and weathering that characterize this type of aquifers (Lachassagne et al., 2001, 2011). There have been a significant amount of studies in this field (Ahmed et al., 2008; Singhal and Gupta, 2010; Ofterdinger et al. 2019), all of which stress the need to improve the knowledge and characterizations of hard rock reservoirs in terms of spatial distributions of hydrodynamic properties at appropriate scales (Butler, 2005; Lachassagne et al., 2014). This type of water source is not as productive as sedimentary, karstic or volcanic aquifers however it is geographically widespread (Dewandel et al., 2011) which makes it well suited to be a fresh water source for farms, villages as well as small and medium size cities (Lachassagne et al., 2011).

Hard rock aquifers are characterized by low to null primary porosity and permeability (Singhal, 2008). Thus, aquifer productivity is mainly linked to fracturing and weathering processes producing a secondary porosity and secondary permeability (Krásný and Sharp, 2007). The hydrogeological structure of hard rock aquifers is commonly divided in three conceptual horizons; from top to bottom (1) a weathered zone with a thickness of up to several tens of meters commonly referred to as saprolite; (2) a fractured zone with depths of a few to hundreds of meters characterized by wellconnected fractures/fissures networks in which the permeability and porosity decrease with depth; and (3) a massive zone usually formed by a massive bedrock with low density of poorly connected fractures and faults acting more as individual flow paths rather than an interconnected network (Krásný et al., 2014).

Geophysical methods are fast, flexible, non-invasive techniques suitable to characterize the spatial variations of subsurface geological structures and hydrogeological properties at various scales and resolutions including in the near surface (Rubin and Hubbard, 2005; Binley et al., 2015), i.e. the first $100 \mathrm{~m}$ that typically host hard rock aquifers (Lachassagne, 2008). One of the main advantages of using geophysics resides in their abilities to provide high resolution, near continuous (Spatial and or temporal) information, instead of only dealing with point data (discrete) typically associated with traditional hydrology studies.

The relationship between geophysical measurements and reservoir properties through the use of petrophysical models has been the focus of much work specifically in the oil industry (Ellis and 
Singer, 2007; Kirsch, 2009; Tiab and Donaldson, 2016) and their application in groundwater studies have been rapidly increasing in the last two decades, which has defined the emergence of an interdisciplinary research field called Hydrogeophysics (Binley et al., 2015; Day-Lewis et al., 2017). A variety of research studies have successfully applied geophysics to solve different quantitative problems in hydrology (Vereecken et al., 2006) and some other used these approaches specifically to model petrophysical properties in carbonate aquifers (Whitman and Yeboah-Forson, 2015) and hard rock aquifers (Descloitres et al., 2008) providing further quantitative information on the aquifer properties including storage properties (porosity, specific yield) and recharge processes.

Very few studies have combined different geophysical methods to model hydraulic properties in complex hard rock aquifers and even less have assessed the uncertainty of these properties (Massuel et al., 2006; Slater, 2007; Chaudhuri et al., 2013;). Electrical resistivity tomography (ERT) is suitable for weathered/fractured aquifer characterization (Pellerin, 2002), particularly to constrain reservoir geometries i.e. to estimate the thickness and variability of weathered (laminated layer) and fractured horizons as well as localized deep fractures zones (Chaudhuri et al., 2013; Belle et al., 2019) or as a monitoring tool for salt tracer tests in complex hard rock systems (Robert et al., 2012). Only a few studies have assessed the relation of geophysical measurements (resistivity and conductivity) with hydraulic properties (porosity and water saturation) in hard rock aquifers due to their complexity and lack for information on petrophysical model input parameters (Leopold et al., 2013; Flinchum et al., 2018, 2019).

This study aimed at assessing the capabilities of the popular ERT technique to quantify the spatial variability of aquifer storage properties in weathered/fractured rock aquifers with high resolution. The study uses in situ ERT data from a 1,305 $\mathrm{m}$ hillslope transect obtained in a mica schist aquifer in Ireland as an analog for basement rock aquifers. Two alternative petrophysical models were considered to estimate porosity from measured resistivities with the aid of complementary in situ information, used for both model parameterization and verification. These data included multi-depth borehole hydraulic data and geophysical logging along with information on the vertical distribution of aquifers' water content as obtained from magnetic resonance sounding, MRS (Legchenko et al., 2017; 
132 Comte et al., 2019). Specifically, this research builds on, and uses in situ data and conceptual

133 knowledge acquired from previous work at the site over the past decade. Comte et al. (2012a)

134 established the aquifer conceptual model including hillslope spatial variability and lateral continuity

135 of weathering profiles, through combining the ERT and borehole hydraulic data with groundwater

136 level monitoring. Caulfield et al. (2014) performed petrographic and mineralogical analyses of

137 borehole cores along with groundwater chemistry to further highlight modern weathering processes

138 and weathering controls on groundwater contribution to surface water. Legchenko et al. (2017)

139 applied Magnetic Resonance Sounding (MRS) to provide estimates, with associated uncertainties, of

140 vertical groundwater storage profiles at several locations along the hillslope. Comte et al. (2019)

141 reconciled previous hydrogeological, ERT, and MRS water content data and further integrated them

142 into a numerical groundwater model to test and verify the conceptual model, including groundwater

143 flow pathways and residence times, against spatiotemporal hydrological monitoring data

144 (groundwater level time series and groundwater ages). These works, in addition to provide relevant data for the present study, suggested a high heterogeneity of groundwater storage, and highlighted the challenges associated with achieving storage characterization and high enough spatial resolution required for better understanding basement rock groundwater regimes and resources response to both short term and long term climate and anthropogenic forcing. In this present study, we therefore focused on a detailed quantitative assessment of the resolution and reliability, including sensitivity and uncertainty analysis, of ERT-derived groundwater storage estimates using popular petrophysical models, along with additional geological information and constraints (conceptual hydrogeological units, water saturation, clay content), and we further verify the results again independent groundwater storage data.

Thus, the specific objectives of this work were: (1) to model the 2D spatial distribution of the aquifer petrophysical properties based on 1D borehole data and the structural-conceptual information provided by the interpretation of $2 \mathrm{D}$ electrical resistivity data; (2) produce $2 \mathrm{D}$ porosity models from the combination of resistivity and petrophysical parameters distributions within the Archie and Waxman \& Smits models; and (3) quantify the sensitivity of the petrophysical models and the 
uncertainty of the final aquifer porosity models (expected to be considerable due to larger parameter uncertainty associated to large scale studies), and further verify them against independent geophysical water content estimates and borehole hydraulic data.

\section{Hydrogeological setting}

The studied aquifer is located in County Donegal, Ireland. (Fig. 1). The Gortinlieve catchment is an upland basin with permanent stream flow, underlain by Precambrian psammites and mica schist of the Dalradian Southern Highland Group and composed of quartz, muscovite, chlorite, albite with secondary minerals such as calcite and iron oxides (Caulfield et al., 2014). The bedrock is covered in places by overburden deposits of glacial till, alluvium, and thin soil/peat layer (Fig. 2). In 2006, the Irish Environmental Protection Agency drilled three borehole clusters (Table 1) as part of a national groundwater monitoring program. They were distributed along the study area at strategic locations that comprehended three elevations (GO1 at $174 \mathrm{~m}$ a.m.s.1.; GO2 at $88 \mathrm{~m}$ a.m.s.l.; GO3 at $33 \mathrm{~m}$ a.m.s.1.) within the catchment (Comte et al., 2012a, 2019; Moe et al., 2010). A first interpretation carried by Moe et al., (2010) identified four hydrogeological units, subsoil (1-3 m below ground surface), transition zone (4-5 m b.g.s.), shallow bedrock (8-19 m b.g.s.) and deep bedrock (30-67 m b.g.s.). Average monthly temperatures fluctuate from $6-14^{\circ} \mathrm{C}$ with an annual rainfall of $1000-1200$ mm (Caulfield et al., 2014). See Comte et al. (2012a, 2019) for a detailed description of hydraulic tests and interpretations. 


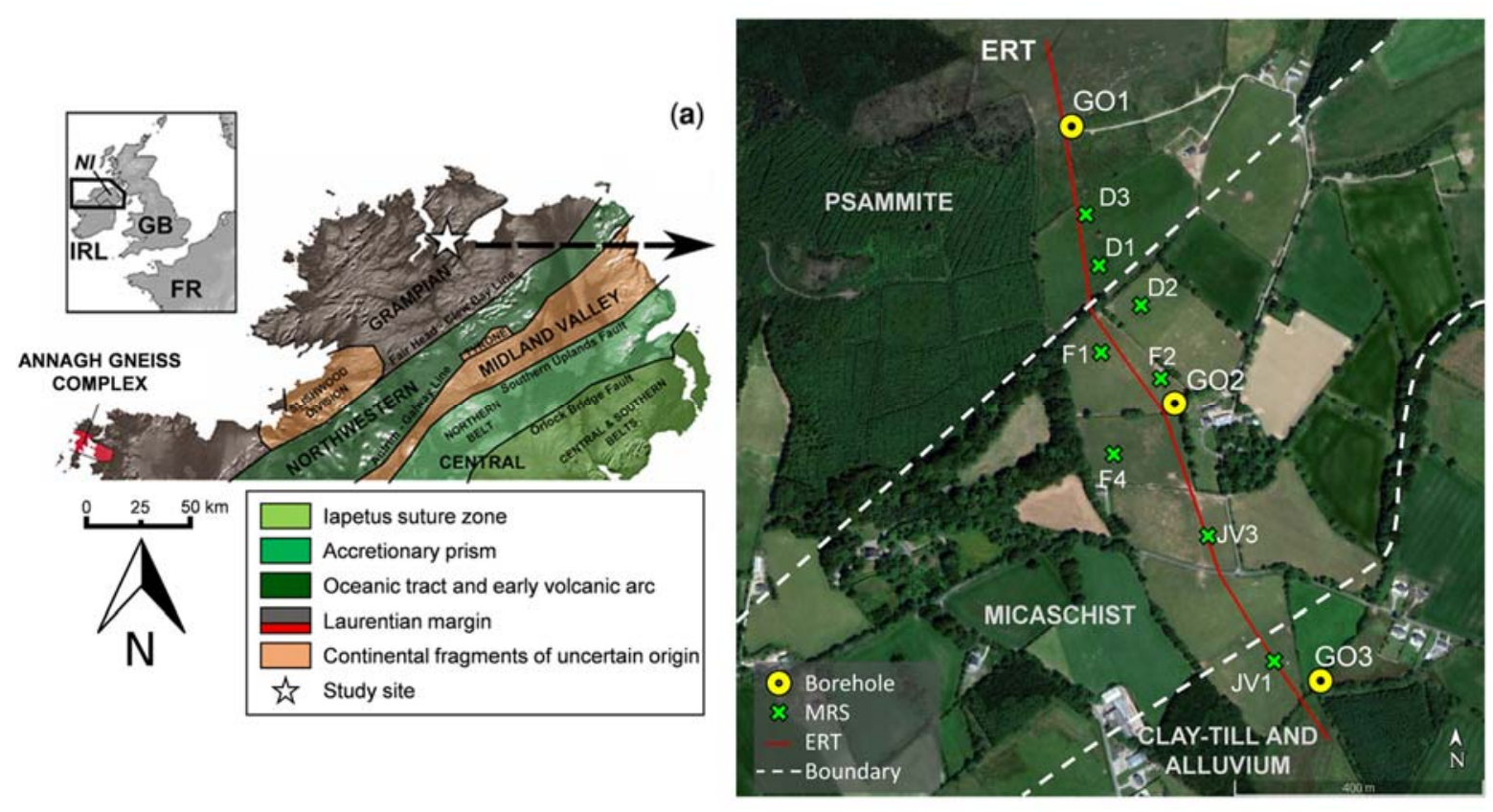

179 Figure 1. Location of the study site. (a) Site location within the geological framework of the Irish

180 basement. (b) Borehole locations and ERT profile, modified from Comte et al. (2019). 


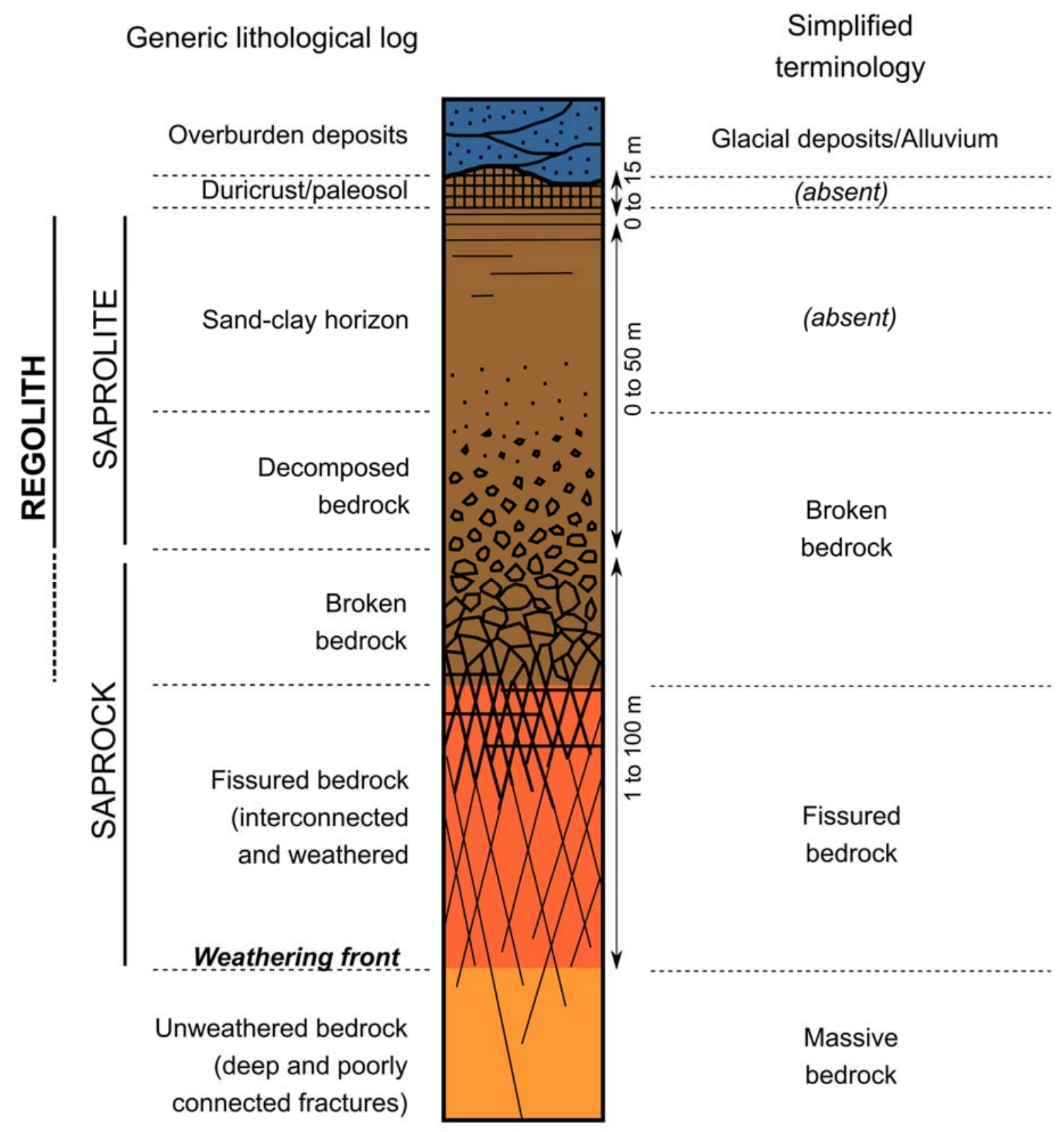

Figure 2. Hydrogeological conceptual model of weathered/fractured rock aquifers in the context of Irish terminology. Modified from Comte et al. (2012a) 


\section{Data and methods}

\subsection{Petrophysical relationship between resistivity and porosity}

The resistivity measurements were the main inputs in the petrophysical modelling used for porosity calculation. The two petrophysical models used in this study were based on Archie's law (Archie, 1942) and its extension developed by Waxman \& Smits (1968). Archie describes a relationship between the electrical conductivity of a clay-free rock, its porosity, and the electrical conductivity of the fluid saturating the pores. Archie's Law is expressed as

$R_{t}=\frac{a R_{w}}{\phi^{m} S_{w}{ }^{n}}$

where $\boldsymbol{R}_{t}$ is the formation resistivity (ohm.m), $\boldsymbol{\phi}$ is the fractional pore volume, i.e. the porosity (-), $\boldsymbol{S}_{\boldsymbol{w}}$ is the fraction of pores containing water, i.e. the saturation (-), $\boldsymbol{R}_{w}(\mathrm{ohm} . \mathrm{m})$ is the water resistivity, and $\boldsymbol{a}, \boldsymbol{m}$ and $\boldsymbol{n}$ are empirical constants known as tortuosity, cementation exponent and saturation exponent respectively. These constants are dimensionless.

To account for clay mineral electrical properties, several studies have proposed empirical modifications of Archie and the most commonly accepted was proposed by Waxman \& Smits (1968). The Waxman \& Smits equation includes additional parameters to quantify the influence of clay and is given by

$\frac{1}{R_{t}}=\frac{\phi_{t}^{m} S_{w}{ }^{n}}{\alpha R_{w}}\left(1+B Q_{v} \frac{R_{w}}{S_{w}}\right)$

where $\boldsymbol{B}$ is the equivalent counterion mobility ( $\left.\mathrm{mho} \mathrm{cm}^{2} / \mathrm{meq}\right)$ expressed as

$B=\left[1-0.6 \exp \left(-0.77 / R_{w}\right)\right] 4.6$

and $\boldsymbol{Q}_{\boldsymbol{V}}$ is the volumetric charge density $(\mathrm{meq} / \mathrm{mL})$ expressed by

$Q_{v}=\rho_{g} \frac{1-\phi}{\phi} C E C$

where $\boldsymbol{\rho}_{g}$ is the grain density of the aquifer and $\boldsymbol{C E C}$ (meq/g) cation exchange capacity (Revil, 1998). For a mixture of clay minerals, the total $\boldsymbol{C E C}$ is given by 
$212 \boldsymbol{X}_{\boldsymbol{i}}$ is the relative fraction of each clay minerals in the fraction of the rock, $\boldsymbol{C E} \boldsymbol{C}_{\boldsymbol{i}}$ is the cation exchange capacity of each of these clay minerals and $\varphi_{\mathrm{w}}$ is the mass fraction of clay in the rock.

Before applying these models, both formation and pore water resistivities must be normalized to a temperature of $25^{\circ} \mathrm{C}$, as temperature also influences electrical conductivity, and $25^{\circ} \mathrm{C}$ is the temperature at which the water saturation equations were developed. The conversion is done using the following equation (Arps, 1953):

$218 \quad R=R_{F}\left[\frac{T+21.5}{T_{F}+21.5}\right]$

where $\boldsymbol{R}$ is the new resistivity calculated at the temperature desired $\left(25^{\circ} \mathrm{C}\right), \boldsymbol{R}_{\boldsymbol{F}}$ resistivity at formation temperature, $\boldsymbol{T}$ is the temperature desired $\left(25^{\circ} \mathrm{C}\right)$ and $\boldsymbol{T}_{\boldsymbol{F}}$ is the formation temperature $\left({ }^{\circ} \mathrm{C}\right)$.

\subsection{Petrophysical model input data}

\subsubsection{Structural-conceptual interpretation of ERT geophysical data}

Geophysical data comprised an ERT profile of 1,305 $\mathrm{m}$ along a catchment hillslope transect crossing the three borehole clusters locations (Fig. 1). The tomography was carried out using a Syscal Pro resistivity meter with 60 electrodes distributed on 5 cables with a spacing of 5 meters, extending the acquisition length by using the roll-along technique. Dipole-dipole (DD) and multi-gradient (mGD) arrays were combined to optimize the resolution of geological structures (Comte et al., 2012b).

Measurement errors (standard deviation after stacking) higher than $4 \%$ were filtered out, in total 1.6\% of the pre-processed raw dataset. The average error for the remaining dataset was $0.13 \%$ with only $2.2 \%$ of the data having errors between $1 \%$ and $4 \%$. Data inversion was implemented using RES2DINV v3.58 (Geotomo Software) with a depth of investigation analysis (DOI) index of 0.1 as proposed by Oldenburg and Li (1999). The overall inversion error was 9.6\% and the model block resistivity uncertainty ranged $1-21 \%$ with an average of $4 \%$ across the section. Further details of acquisition and processing are in Comte et al. (2012a). 
ERT inversion results revealed a subsurface layering with strong resistivity changes (Fig. 3a). Comte et al. (2012a) proposed a conceptual interpretation with low resistivities $(<500 \mathrm{ohm} . \mathrm{m})$ representing the alluvium and clay-till sediments, fully saturated in their majority. A high resistivity zone $(>1,000$ ohm.m) mainly characterized by unsaturated psammite schist with low clay content in the NNW zone of the study area. Below this layer, the resistivity increased ranging from 500-2500 ohm.m interpreted as the weathered/fissured schist. At the bottom of the profile, the most resistant zone (> $1000 \mathrm{ohm} . \mathrm{m})$ is formed by unweathered mica schist with very low fracture density (Fig. 3b).

A refined interpretation was proposed in this case study. Using prior understandings (Moe et al., 2010; Comte et al., 2012a) of borehole and ERT data, a model comprised of five hydrogeological units has been used: (1) a deepest layer (massive bedrock, MB) of high resistivities (> 1,000 ohm.m) with low to null clay content and a low fracture density; (2) over the MB, the resistivities ranging from 500-3,000 ohm.m represents a weathered/fissured schist (fissured bedrock, FB) with higher clay content and the major thickness variability $(5-30 \mathrm{~m})$; (3) the third layer (broken bedrock, BB) is characterized by high resistivities at high elevation (300-2,500 ohm.m) decreasing in SSE direction with an unsaturated zone and relatively low clay content (clay-leached horizon, Comte et al. 2019); (4) resistivities below $750 \mathrm{ohm} . \mathrm{m}$ are considered as the glacial deposit's unit, unsaturated in some areas and intercalated by the BB unit; (5) the alluvium is the fifth unit in this model, with presence only in the surrounding area of the GO3 borehole, it has the lowest resistivities ( $<300 \mathrm{ohm}$.m) in the ERT profile (Fig. 3c).

\subsubsection{Borehole logging analysis}

The boreholes in the Gortinlieve catchment were drilled in three clusters (GO1, GO2, GO3). GO1 and GO2 have three wells, while GO3 has four wells to monitor the catchment at different hydrogeological units (Table 1). Logging analysis for this case study included gamma ray (GR) and temperature $(\mathrm{T}) \operatorname{logs}$. 
Table 1. Borehole clusters of monitoring programme by Irish EPA. Modified from Moe et al. (2010).

\begin{tabular}{|c|c|c|c|c|c|}
\hline $\begin{array}{l}\text { Monitoring } \\
\text { Well }\end{array}$ & $\begin{array}{l}\text { Depth } \\
\text { (m) }\end{array}$ & Borehole completion & $\begin{array}{l}\begin{array}{l}\text { Uncased } \\
\text { (open) } \\
\text { Interval (m) }\end{array} \\
\end{array}$ & Zone & $\begin{array}{l}\text { Elevation } \\
\text { (m. a. s. 1.) }\end{array}$ \\
\hline GO1-Deep & 76.20 & Uncased 6 in. borehole & $46.60-76.20$ & $\begin{array}{l}\text { Massive } \\
\text { bedrock }\end{array}$ & \multirow{3}{*}{174} \\
\hline GO1-Shallow & 13.11 & Uncased 6 in. borehole & $4.72-13.11$ & $\begin{array}{l}\text { Fissured } \\
\text { bedrock }\end{array}$ & \\
\hline GO1-Transition & 2.44 & $\begin{array}{l}6 \text { in. PVC screen with } 2 \mathrm{~mm} \\
\text { slots, screen covered with } 300 \text { - } \\
\text { micron filter fabric }\end{array}$ & $0.65-2.20$ & $\begin{array}{l}\text { Broken } \\
\text { bedrock }\end{array}$ & \\
\hline GO2- Deep & 67.06 & Uncased 6 in. borehole & $29.26-67.06$ & $\begin{array}{l}\text { Massive } \\
\text { bedrock }\end{array}$ & \multirow{3}{*}{88} \\
\hline GO2-Shallow & 15.24 & Uncased 6 in. borehole & $7.92-15.24$ & $\begin{array}{l}\text { Fissured } \\
\text { bedrock }\end{array}$ & \\
\hline GO2-Transition & 3.05 & $\begin{array}{l}6 \text { in. PVC screen with } 2 \mathrm{~mm} \\
\text { slots, screen covered with } 300 \text { - } \\
\text { micron filter fabric }\end{array}$ & $0.63-2.85$ & $\begin{array}{l}\text { Broken } \\
\text { bedrock }\end{array}$ & \\
\hline GO3-Deep & 53.34 & Uncased 6 in. borehole & $36.27-53.34$ & $\begin{array}{l}\text { Massive } \\
\text { bedrock }\end{array}$ & \multirow{4}{*}{33} \\
\hline GO3-Shallow & 23.77 & Uncased 6 in. borehole & $12.19-23.77$ & $\begin{array}{l}\text { Fissured } \\
\text { bedrock }\end{array}$ & \\
\hline GO3-Transition & 7.15 & $\begin{array}{l}6 \text { in. PVC screen with } 2 \mathrm{~mm} \\
\text { slots, screen covered with } 300- \\
\text { micron filter fabric }\end{array}$ & $4.73-6.95$ & $\begin{array}{l}\text { Broken } \\
\text { bedrock }\end{array}$ & \\
\hline GO3-Subsoil & 3.35 & $\begin{array}{l}6 \text { in. PVC screen with } 2 \mathrm{~mm} \\
\text { slots, screen covered with } 300 \text { - } \\
\text { micron filter fabric }\end{array}$ & $1.63-3.20$ & Subsoil & \\
\hline
\end{tabular}




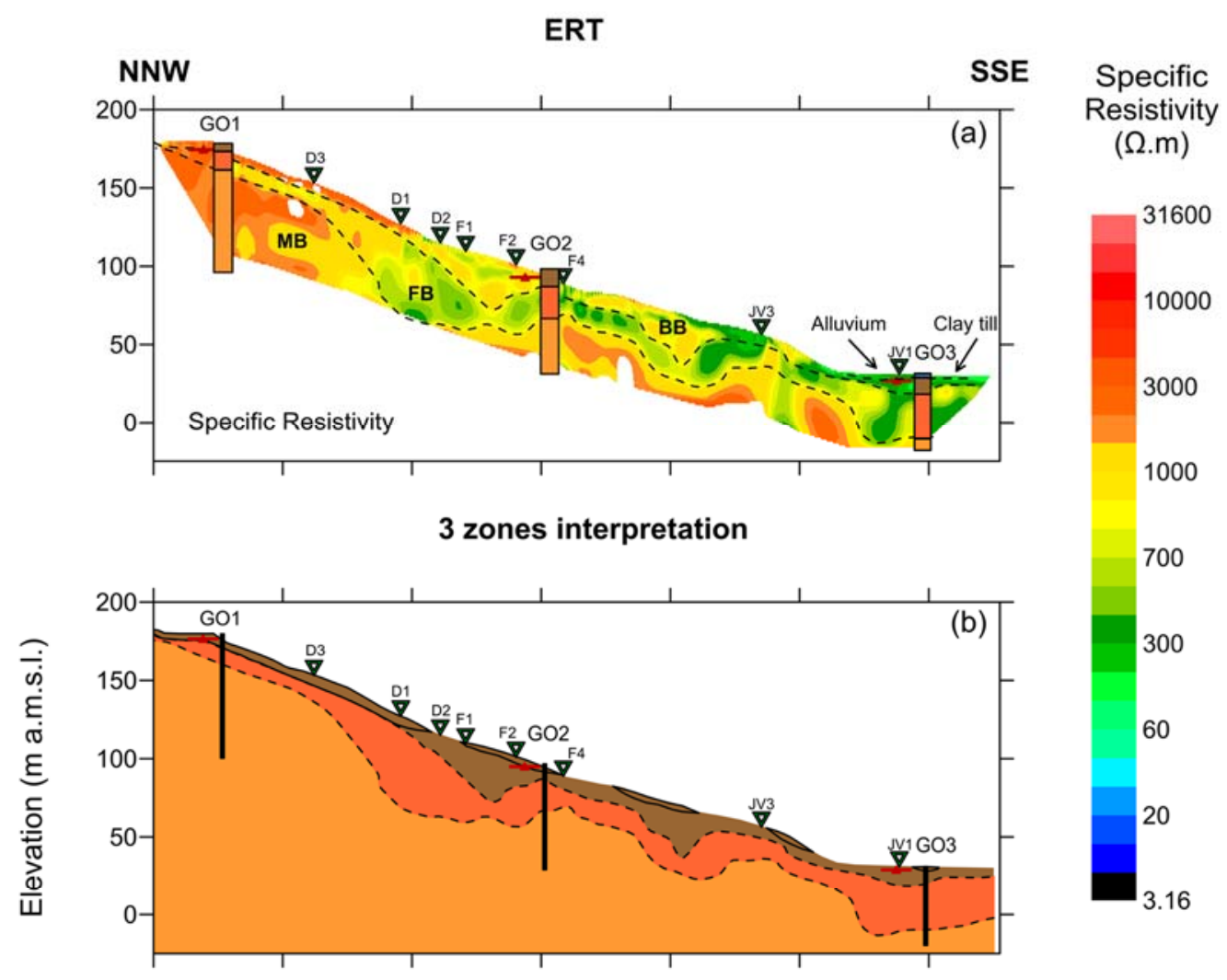

5 zones interpretation
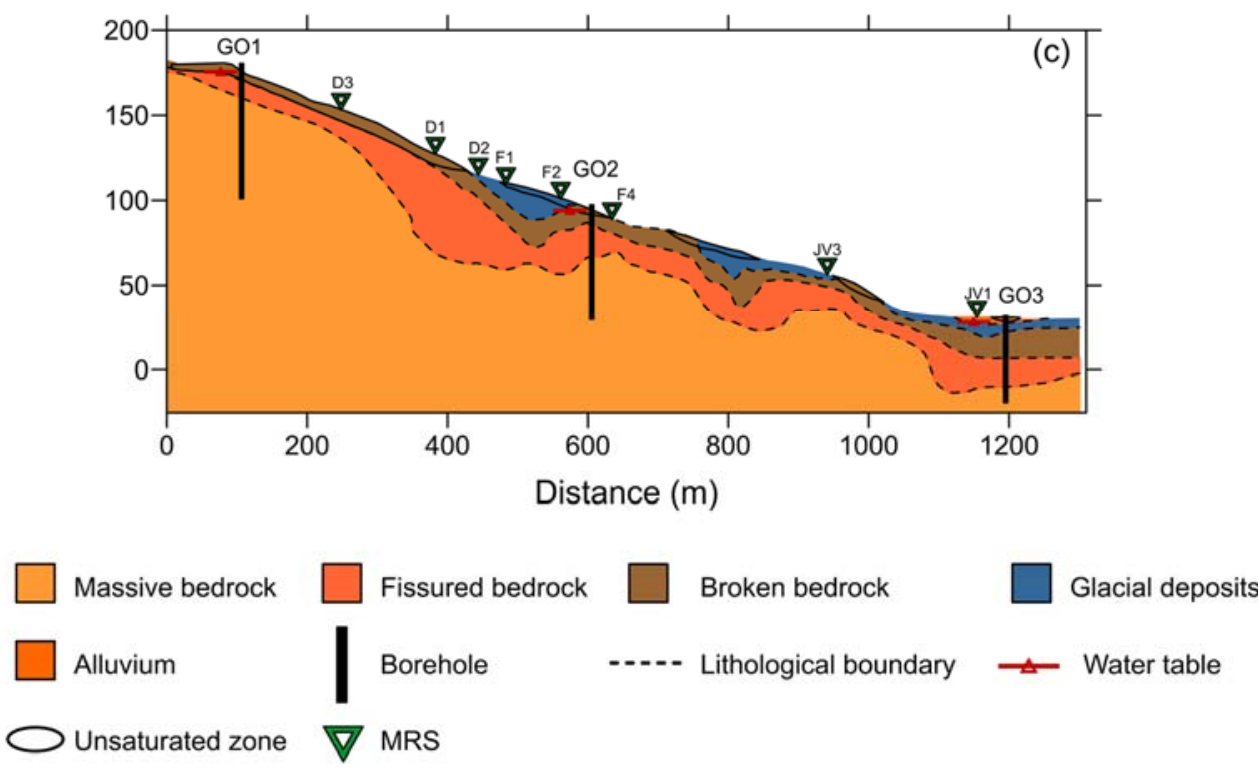

265 Figure 3. Inverse resistivity model of the Gortinlieve catchment along with two alternative

266 hydrogeological conceptual interpretations. GO1, GO2, GO3 indicate borehole locations and triangles

267 indicate locations of magnetic resonance soundings. 
270

271

272

274

275

276

277

279

The bedrock in this study area has a significant content of clay deposited in the fractures due to weathering processes in the aquifer (Caulfield et al., 2014) reducing the pore space. Clays are finedgrained high porosity minerals or soil material with a low hydraulic conductivity, so the water cannot easily flow through them (Moreno-Maroto and Alonso-Azcárate, 2018). For the application of the Waxman \& Smits model, unlike Archie's model, the total CEC of the rock was required and computed using the Eq. (5) using (1) the nature (with known CEC ranges for individual minerals $\boldsymbol{C E C}_{\boldsymbol{i}}$ are reported in Table 2) and respective proportions of clay minerals $\boldsymbol{X}_{\boldsymbol{i}}$ for the site as reported from the analysis of borehole cuttings by Caulfield et al. (2014) and (2) total clay volumes, expressed a clay mass fraction in the bulk rock $\varphi_{\mathrm{w}}$, estimated using gamma ray (GR) logs.

The gamma ray log measures the natural radioactivity of a formation (expressed in API units) and it can be used to estimate the clay weight fraction. The gamma ray logs measure the radioactive material of the formations surrounding the borehole at a constant rate by measuring three primary isotopes Potassium (K), Thorium (T) and Uranium (U) which are highly concentrated in clay minerals. Therefore, GR logs mostly respond to parts of the rock formation matrix that is weathered into clays. Water circulation is a major factor for weathering, and since it is primarily controlled by fractures, it is expected that weathering clays predominantly occur in and in the vicinity of hydraulically active fracture (sometimes subsequently clogging fractures and hampering flow).

Clay weight fractions were obtained from GR by assuming two relations specifically for this case study. First, a linear relation expressed as

$$
\varphi_{w}=I_{G R}=\frac{G R_{\log }-G R_{\min }}{G R_{\max }-G R_{\min }}
$$

where the $\boldsymbol{I}_{\boldsymbol{G} \boldsymbol{R}}$ is the gamma ray index, $\boldsymbol{G R}_{\boldsymbol{l o g}}$ is the gamma ray $\log$ reading, $\boldsymbol{G} \boldsymbol{R}_{\min }$ is the minimum gamma ray value corresponding to a clean clay point $(0 \%)$ and $\boldsymbol{G R}_{\max }$ is the maximum gamma ray value in a saturated clay point $(100 \%)$ according to pure clay values for the observed clay mineral as reported by Revil et al., (1998): Chlorite,180 API; Illite, 250 API; Montmorillonite, 150 API; Muscovite, 250 API. Second, a non-linear relation expressed as 
$\varphi_{w}=0.33 \times\left(2^{2 I_{G R}}-1\right)$

296

297

298

299

300

301

302

303

304

305

\begin{tabular}{lll}
\hline Clay mineral & $\begin{array}{l}\text { CEC } \\
(\mathbf{m e q} / \mathbf{1 0 0 g})\end{array}$ & $\begin{array}{l}\text { Selected CEC } \\
(\mathbf{m e q} / \mathbf{1 0 0 g}) *\end{array}$ \\
\hline Chlorite & $10-40$ & 20 \\
Illite & $10-40$ & 20 \\
Montmorillonite & $80-120$ & 90 \\
Muscovite & $1-10$ & 1
\end{tabular}
volume analysis, see the supplementary material (S1). (Dolcater et al., 1972; Meunier, 2005; Christidis, 2010; Bibi et al. 2016).
306

307

308

309

310

311

312

313

that compensate for the different clay mineral proportions for shale (Revil et al., 1998; Ellis and Singer, 2007). The gamma ray index $\left(I_{G R}\right)$ was scaled into percentage to estimate the clay weight fraction of the formations. Borehole analysis for clays (Caulfield et al. 2014) described constant clay mineralogy across the study area, with variations in clay mineral relative proportions and clay weight fractions according to the hydrogeological unit. Average values for clay weight fraction were estimated from GR logs for each borehole and hydrogeological zone (Table 3). For detailed clay

Table 2. Cation exchange capacity (CEC) of the clay minerals present in the Gortinlieve catchment

\footnotetext{
* Distributed according to their clay mineral volume using method proposed by Revil et al. (1998).
}

The $\mathrm{I}_{\mathrm{GR}}$ yielded clay volumes with small variations between boreholes GO1 and GO2. In contrast, the GO3 borehole had higher variations of clay volume decreasing from the BB to the FB. The major impact of clay volume changes was observed when the CEC of each mineral was introduced in the Waxman \& Smits model, quantifying the variations in the total CEC values (Eq. 5). According to the clay mineralogy, all three main bedrock hydrogeological units (BB, FB, MB) are dominated by muscovite. Outside the FB in GO2, the most deeply weathered location, muscovite accounts for between $40 \%$ and over $80 \%$ of all clay minerals. The FB unit has consistently the most balanced clay mineralogy (in proportions of muscovite, chlorite, illite, and montmorillonite) and is simultaneously, 
316 because of its highest proportions of illite and montmorillonite, the unit with the highest total CEC. In

317 contrast, the MB is devoid of both minerals due to insignificant weathering, while the $\mathrm{BB}$ has

318 relatively low proportions of these minerals, finally resulting in lower CECs than the FB for both

319 units. This distribution is interpreted as secondary clays produced by weathering of predominantly the

$320 \mathrm{BB}$, and to a lesser extend the $\mathrm{FB}$, being leached from $\mathrm{BB}$ and accumulate in fissures and fractures of

321 the FB unit. As this pattern in clay proportions is very consistent within each hydrogeological unit

$322(\mathrm{BB}, \mathrm{FB}, \mathrm{MB})$ we assumed that mineralogy and $\mathrm{CEC}$, and their associated uncertainty, can reasonably

323 be interpolated across each unit along the whole $1300 \mathrm{~m}$ transect.

Table 3. Clay minerals identified in the groundwater monitoring wells. Gamma ray mean value per zone using linear and non-linear relation. Clay weight fraction and total CEC per zone. Modified from

Comte et al. (2019).

\begin{tabular}{|c|c|c|c|c|c|c|c|}
\hline & $\begin{array}{l}\text { Chlorite } \\
(\%)\end{array}$ & $\begin{array}{l}\text { Illite } \\
\text { (\%) }\end{array}$ & $\begin{array}{l}\text { Montmorillonite } \\
(\%)\end{array}$ & $\begin{array}{l}\text { Muscovite } \\
(\%)\end{array}$ & $\begin{array}{l}\text { Natural } \\
\text { gamma } \\
\text { (cps) }\end{array}$ & $\begin{array}{l}\text { Clay } \\
\text { weight } \\
\text { fraction } \\
(\%) \\
\end{array}$ & $\begin{array}{l}\text { Total CEC } \\
\text { (meq/100g) }\end{array}$ \\
\hline \multicolumn{8}{|l|}{ GO1 } \\
\hline Broken bedrock (BB) & 26.8 & 7.5 & 7.9 & 57.9 & 116 & 49.7 & 5.9 \\
\hline Fissured bedrock (FB) & 20.2 & 21.7 & 18.1 & 40.0 & 111 & 48.6 & 11.2 \\
\hline Massive bedrock (MB) & 34.2 & 0.0 & 0.0 & 65.8 & 102 & 42.6 & 1.7 \\
\hline \multicolumn{8}{|l|}{$\mathrm{GO} 2$} \\
\hline Broken bedrock (BB) & 11.5 & 8.4 & 4.8 & 75.4 & 101 & 40.1 & 3.1 \\
\hline Fissured bedrock (FB) & 3.3 & 46.7 & 31.9 & 18.0 & 102 & 44.7 & 17.3 \\
\hline Massive bedrock (MB) & 17.5 & 0.0 & 0.0 & 82.5 & 116 & 46.6 & 1.2 \\
\hline \multicolumn{8}{|l|}{ GO3 } \\
\hline Alluvium & 13.5 & 5.4 & 3.9 & 77.2 & 40 & 13.3 & 0.9 \\
\hline Glacial till & 13.5 & 5.4 & 3.9 & 77.2 & 45 & 15.5 & 1.1 \\
\hline Broken bedrock (BB) & 13.5 & 5.4 & 3.9 & 77.2 & 78 & 30.0 & 2.0 \\
\hline Fissured bedrock (FB) & 5.5 & 39.6 & 26.6 & 28.3 & 41 & 14.8 & 4.8 \\
\hline Massive bedrock (MB) & 17.5 & 0.0 & 0.0 & 82.5 & 116 & 46.6 & 1.2 \\
\hline
\end{tabular}


Not all the input parameters for the petrophysical models were available from the study site: this includes the rock density, porous media tortuosity, and cementation exponent which are empirical parameters that have been constrained from previously published literature (Table 4). The cementation exponent $(m)$ is the most important parameter in Archie's law, depending on the porosity and fracture density (Archie, 1942; Aguilera, 1976). These authors found a relationship between the pore connectivity and the fracture network stating that high fracture content is associated with a low cementation exponent (Aguilera, 1976). Other authors suggested that the shape of the grains and the pores are more significant for variations of the cementation exponent than other properties (Salem and Chilingarian, 1999). More recent studies claimed that $m$ is dependent on the connectedness (transport pathways), taking into account its variation as a function of porosity and the connectivity of the matrix. The connectedness, also known as conductivity formation factor, describes how the electrical conductivity of a fluid is modified by the presence of solid non-conducting grains. (Glover, 2009, 2010).

Additionally, the studied hard rock aquifer had a significant volume of clay, which can lead to an increase of $m$ depending on the volume and type of the clay (Waxman \& Smits, 1968; Salem and Chilingarian, 1999). As a conclusion, the cementation exponent is not easy to determine because is highly affected by several factors. However, previous studies (Salem, 2001; Tabibi and Emadi, 2013; Kazakis et al., 2016) have proposed $m$ values for weathered/fractured aquifers with clay content to predict reservoir quality and performance. In this work, $m$ was calibrated using the range of values provided by these studies (Table 4).

An average density range was calculated for each hydrogeological unit according to the rock types identified in the borehole cuttings. The third of these parameters was the tortuosity $(\alpha)$, defined as a ratio of fluid flow in a porous media (Pisani, 2011; Tokan-Lawal et al., 2014). For this study, the value of $\alpha$ was fixed at 1.4 (Urish, 1981; Aguilera, 2008; Piedrahita and Aguilera, 2017) for all the 
hydrogeological units due to its low impact in zones with low porosity, a primary characteristic of this catchment.

Table 4. Parameters used to quantify porosity for Archie and Waxman \& Smits model. Modified from Comte et al. (2019)

\begin{tabular}{lllll}
\hline & $\begin{array}{l}\text { Water } \\
\text { temperature } \\
\left({ }^{\circ} \mathbf{C}\right)\end{array}$ & $\begin{array}{l}\text { Cementation }_{\text {exponent }^{\mathbf{a}}} \\
\text { Alluvium }\end{array}$ & $\begin{array}{l}\text { Rock density } \\
\left(\mathbf{g} / \mathbf{c m}^{\mathbf{3}}\right)^{\mathbf{b}}\end{array}$ & $\begin{array}{l}\text { Water } \\
\text { resistivity } \\
(\mathbf{\Omega . m})\end{array}$ \\
Glacial till & $13.5-16.0$ & 1.8 & $1.50-2.20$ & $22.22-22.65$ \\
Broken bedrock & $12.1-16.0$ & 2.5 & $1.60-2.0$ & $22.22-29.63$ \\
Fissured bedrock & $12.8-14.2$ & 2.0 & $2.45-2.55$ & $22.22-37.04$ \\
Massive bedrock & $12.7-13.1$ & 1.5 & $2.6-2.70$ & $20.0-34.48$ \\
${ }^{a}$ Cementation exponent $($ Salem, 2001; Tabibi and Emadi, 2013; Kazakis et al., 2016)
\end{tabular}

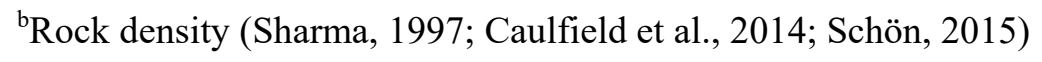

The Archie and Waxman \& Smits models were applied considering different saturation values $\left(\mathrm{S}_{\mathrm{w}}\right)$ in the aquifer unsaturated zone. Both models were quantified using 4 percentages of saturation $(100 \%$, $75 \%, 50 \%$, and $25 \%$ ) introduced in the respective equations (Eq. 1,2). The unsaturated zone was structurally delineated from ERT as representing a thin shallow layer of up to a few meters depending on the location.

\subsection{Spatial interpolation of borehole-based petrophysical parameters}

Considering that some of the input data for the petrophysical models were only available at 3 borehole locations, these parameters were spatially interpolated and extrapolated to provide 2D spatial distributions over the same grid as the input ERT data. Interpolation was performed following three conceptual-structural scenarios; (1) simple (unconstrained) interpolation, (2) structurally constrained 
interpolation using 3 conceptual hydrogeological units based on the ERT interpretation and (3) constrained using 5 conceptual units based on the ERT interpretation. The process was carried out using SURFER v13.0 by Golden Software considering three interpolations methods; nearest neighbor, triangular interpolation, and kriging.

Borehole parameters included in the interpolation process were water temperature $(T)$, water resistivity $\left(R_{w}\right)$, cementation exponent $(m)$, rock density $(\rho)$, and cation exchange capacity $(C E C)$. The nearest-neighbor method was finally chosen for subsequent work as being less subject to artifacts than the other two methods.

\subsection{Sensitivity and uncertainty analysis}

Sensitivity analysis (SA) aimed at exploring the robustness and accuracy of model results for either Archie or Waxman \& Smits by understanding the impact of the variations in individual input parameters on the outputs of the model (Balaman, 2019). The SA measured the impact of change in the model by introducing increments or decrements of $\pm 15 \%$ and $\pm 30 \%$ in the parameters and quantifying the percentage change of each of them. This enabled us to distinguish between highleverage parameters, whose values have a significant impact on the model behavior and low-leverage parameters, whose value have minimal impact in the outputs (Jørgensen and Fath, 2011), and focus on the significant parameters to reduce uncertainty and increase the reliability of the model due to the high sensitivity of Archie's and Waxman \& Smits.

Uncertainty analysis (UA) was further carried out to quantify the variability of the final model output that is due to the combined variability of all input parameters, which is considerable in a large-scale study. The following workflow was applied: (1) identify the model input parameters subject to uncertainty ( $\alpha$ and $\mathrm{R}_{\mathrm{w}}$ are fixed values for maximum and minimum models; ERT measurement errors of $0.13 \%$ in average were disregarded as negligible compared to the subsequent resistivity inversion error of $9.6 \%$, and the average resistivity model block error of $4 \%$, see section 3.2 .1 ); (2) quantify the variations (uncertainty) of all input parameters, in this case, according to hydrogeological conditions; 
399

400

401

402

403

404

405

406

407

408

409

410

411

412

413 For our study, we used NUMIS ${ }^{\text {plus }}$ and NUMIS ${ }^{\text {poly }}$ MRS equipments manufactured by IRIS

414 instruments (France). In Gortinlieve catchment, 11 MRS stations were located along the ERT profile

415

416

417

(3) generate maximum and minimum values of each parameter; (4) compute the maximum and minimum model outputs; and (5) calculate the relative uncertainty (Geffray et al., 2019).

In this work, all input parameter errors were evaluated with minimum and maximum values according to hydrogeological conditions (Table 5). This provided quantification of the relative uncertainty for each parameter, and the petrophysical models in a 2D distribution. Additionally, the average relative uncertainty per zone was obtained for Archie's and Waxman \& Smits models, as in Eq. 9:

$R U=\frac{A U}{M M} \times 100 \%$

where RU is the relative uncertainty, $\mathrm{AU}$ is the absolute uncertainty and MM is the magnitude of measurement.

Table 5. Parameters considered for uncertainty analysis with ranges of values and relative uncertainties across the three hydrogeological units.

\begin{tabular}{lll}
\hline Parameter & $\begin{array}{l}\text { Full range of } \\
\text { values }\end{array}$ & $\begin{array}{l}\text { Min-Max Rel. } \\
\text { uncertainty (\%) }\end{array}$ \\
\hline Cementation exponent $(m)$ & $1.4-2.6$ & $4-7$ \\
Total CEC $(\mathrm{meq} / 100 \mathrm{~g})$ & $1.10-30.03$ & $49-150$ \\
Density $\left(\mathrm{g} / \mathrm{cm}^{3}\right)$ & $2.35-2.90$ & $2.6-3.0$ \\
Formation resistivity $\left(R_{t}\right)(\Omega . \mathrm{m})$ & $125-39,301$ & $1-21$ \\
Saturation water $\left(\mathrm{S}_{\mathrm{w}}\right)$ & $0.25-1$ & $0-75$ \\
\hline
\end{tabular}

3.5. Model verification using water storage estimates from $1 D$ magnetic resonance sounding with three stations situated as close as possible to the boreholes (Fig. 1). Three of them were rejected because of low signal-to-noise ratio (SNR) and the remaining 8 MRS measurements were used in this study (Comte et al., 2019). SAMOVAR software package was used to run one-dimensional inversion 
of MRS data. See Legchenko et al. (2017) for a detailed description of processing and inversion of

419 MRS data. Accuracy of MRS results depends on the SNR defined by the ambient electromagnetic noise, the target location relative to the measuring loop, and the amount of water in the subsurface (Legchenko et al., 2011). The study area is characterized by a low porosity aquifer and the third condition caused the major effect in the data quality. In general, MRS resolution and sensitivity degrade with the increasing depth to investigated aquifer formation, which limits the depth of investigation with MRS.

Pumping and recovery tests were previously carried out by Comte et al. (2012a) in each borehole of the study site and further interpreted to provide values of transmissivity, hydraulic conductivity, and storativity (see Comte et al., 2012a, for acquisition methodology and interpretation results). These values, especially storativity, would be representative of a very small volume around the open boreholes due to the low pumping rate possible in such low productivity aquifer, and more so for the deep boreholes. As a result, values could be affected by small scale heterogeneities (e.g. preferential flow pathways) and possibly locally enhanced fracturing associate to the downhole hammer drilling process as well as washing of clay clogging in existing fractures due to drilling fluids. To limit the influence of small scale heterogeneities, the storativity values in each bedrock zone intersected by the boreholes (BB, FB, MB), were averaged to provide one value per zone (Table 6). Average storativity values were then compared to corresponding average values of ERT-derived porosity (Archie and Waxman \& Smits) and MRS-derived water content for each zone. 
444 Table 6. Storativity values per zone (from Comte et al., 2012a)

\begin{tabular}{lllll}
\hline Zone & $\begin{array}{l}\text { Storativity } \\
\text { average (-) }\end{array}$ & Min & Max & Data points \\
\hline $\begin{array}{l}\text { Broken bedrock } \\
\text { (BB) }\end{array}$ & 0.05 & 0.05 & 0.05 & 2 \\
$\begin{array}{l}\text { Fissured bedrock } \\
\text { (FB) }\end{array}$ & 0.01 & 0.001 & 0.02 & 3 \\
$\begin{array}{l}\text { Massive bedrock } \\
(\mathrm{MB})\end{array}$ & 0.005 & 0.005 & 0.005 & 2 \\
\hline
\end{tabular}

445

\section{Results}

\subsection{Spatial distribution of input parameters for petrophysical models}

The results of interpolating all the petrophysical model input parameters using the nearest neighbor algorithm (Fig. 4) matched overall the constraints (input data values) at the borehole locations. However, the use of a non-structurally constrained interpolation developed artifacts in the data distribution producing unrealistic geological structures. In detail, $C E C$ spatial patterns exhibited a compartmentalized tabular distribution, with strong lateral and vertical changes. The tabularity angle was controlled by the value applied in the search limits $\left(6.5^{\circ}\right.$ taken as the average topographical slope). Similar behavior was found in the other parameters $\left(m, \mathrm{R}_{\mathrm{w}}, \mathrm{T}, \rho\right)$ with a lower degree of change in all directions due to the low variability of the initial data for the model without structural constraints.

The two structurally-constrained interpolations (with 3 and 5 zones, respectively) produced more realistic parameter distributions. Both structurally-constrained interpolations had similar outputs in the upper $1000 \mathrm{~m}$ of the modeled profile, slightly differing in the lower $500 \mathrm{~m}$ beneath the valley flat. In general, the 5 structural unit model distribution suffered a 'pull-up' of the data in the vertical direction over $500 \mathrm{~m}$. Comparing the models of 5 and 3 zones, the 5 zones model suffered a decrease in values for $C E C, m$, and $R_{w}$ in the $\mathrm{MB}$ and $\mathrm{FB}$ while an increase for $T$ and $\rho$ in the $\mathrm{MB}$ and $\mathrm{FB}$ in the surrounding area near the GO3 borehole. $C E C$ interpolation yielded a distribution highly influenced by the hydrogeological units' model, having the highest values ( $>0.11 \mathrm{meq} / \mathrm{g})$ in the FB specifically 
465 in the center zone of the aquifer. In the case of $m$, the difference between the two structurally-

466 constrained interpolations demonstrated that the major impact occurs in the last $500 \mathrm{~m}$ of the modeled

467 profile, keeping a smooth lateral and vertical distribution of the data that perfectly delineates the two

468 hydrogeological conceptual models.

469 Interpolation of rock density, with a low variation $\left(2.4-2.9 \mathrm{~g} / \mathrm{cm}^{3}\right)$ for the rock minerals encountered

470 in the study area produced similar patterns as $m$, having a distribution with smooth vertical and lateral

471 changes. $R_{w}$ and $T$ interpolation exhibited significantly different spatial patterns than other parameters,

472 with large variability and relative compartmentalization in lateral directions with minor influence of

473 the structural constraints in the interpolations. This is due to these hydrogeological parameters $\left(R_{w}\right.$ and

$474 T$ ) having much larger lateral (upslope-downslope) variability than vertical (depth) variability.

475 Interpolated ranges of values for these parameters are within the input data limits $\left(R_{w}=18-36 \mathrm{ohm} . \mathrm{m}\right.$;

$\left.476 \mathrm{~T}=12-16^{\circ} \mathrm{C}\right)$. 

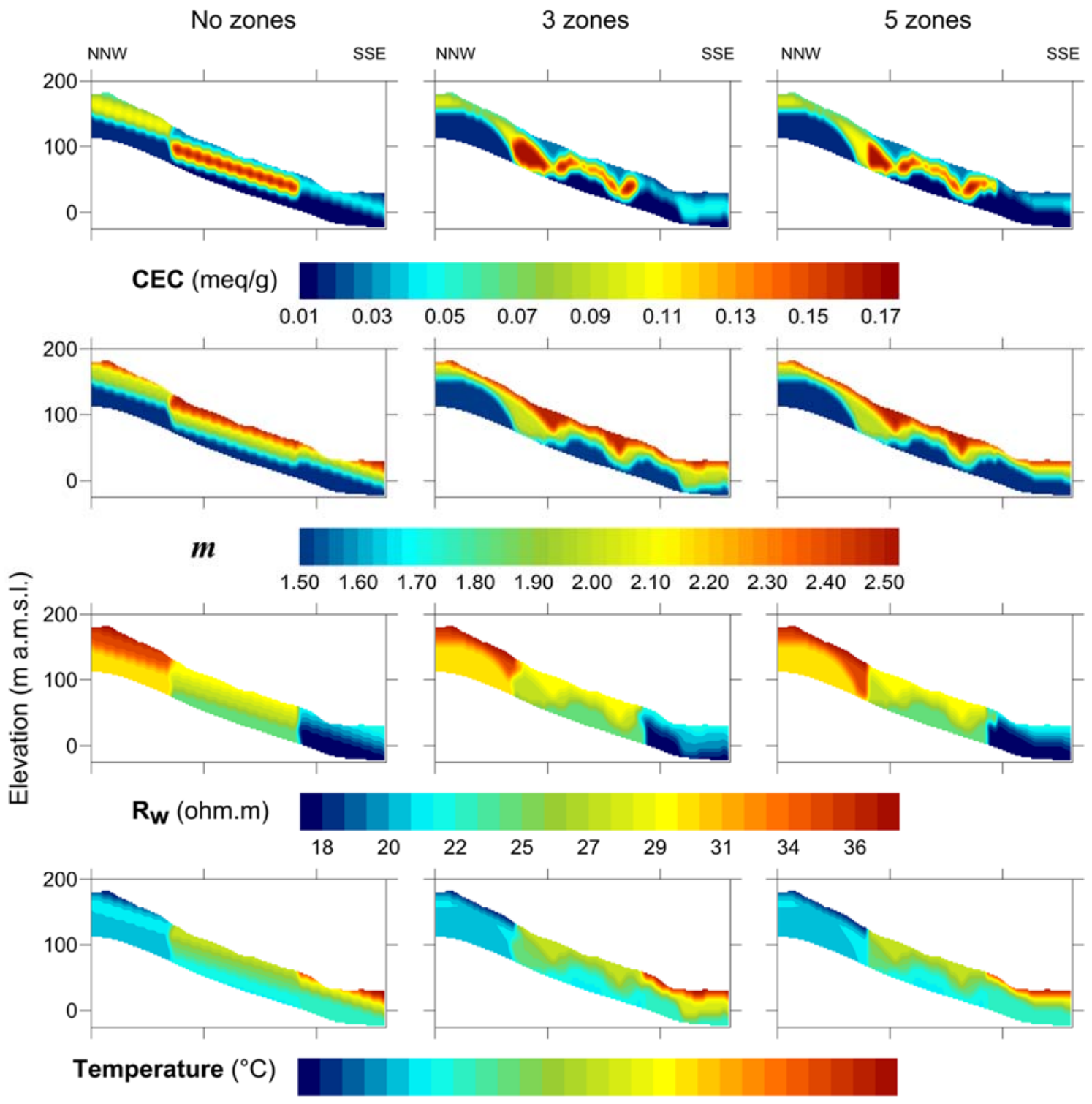

Density $\left(\mathrm{g} / \mathrm{cm}^{3}\right)$

$\begin{array}{llllllll}2.44 & 2.50 & 2.56 & 2.62 & 2.68 & 2.74 & 2.80 & 2.86\end{array}$

478 Figure 4. Nearest neighbor interpolation results of borehole-based petrophysical parameters; cation

479 exchange capacity $(\mathrm{CEC})$; cementation exponent $(\mathrm{m})$; water resistivity $\left(\mathrm{R}_{\mathrm{w}}\right)$; temperature $(\mathrm{T})$ and rock

480 density ( $\rho$ ); without (single unit) and with (3 units and 5 units) structural constraints based on conceptual interpretation of resistivity model. 
483

484

485

486

487

488

489

490

491

492

493

494

495

496

497

498

499

500

501

502

503

504

505

506

507

508

The 2D porosity models resulting from computing the 2D inverted ERT data (Fig. 3a) and the 2D interpolated parameter distribution (Fig. 4) in the two selected petrophysical models (Archie and Waxman \& Smits) are presented in Fig. 5. As expected, the conceptual constraints used when interpolating the petrophysical input parameters had a major influence on the final spatial distribution of porosities. The porosity distribution obtained with no conceptual constraints exhibits tabular layering of massive, fissured, and broken bedrock. Uphill, porosities were an order of magnitude lower than in the mid-slope and downslope areas, with abrupt changes in porosities. A distribution that did not match well the initial structural interpretation of the resistivity profile.

Distributions using 3 and 5-zone structural constraints showed spatial patterns of porosity that better match the original ERT interpretation and associated conceptual model. Highest porosity values were found in the shallow (broken) bedrock characterized by lower resistivities. The deep and intermediate zones (MB and $\mathrm{FB}$ ) had the lowest values of porosity associated with fracture density and aperture as well as weathering intensity (secondary clay content) decreasing with depth. The downslope area, nearby GO3 borehole, exhibited the highest porosity values of all three conceptual models, with a vertical distribution largely controlled by the applied structural constraints. The generally lower porosities obtained uphill for all models were consistent with the different, less weathering-prone psammite lithology as evidenced from outcrop observation and ERT result showing thinner broken and fissured horizons.

Archie's model overall produced porosity values ranging between $3 \times 10^{-2}$ (i.e. $3 \%$ ) to $7 \times 10^{-1}$ (i.e. $70 \%$ ) for the three conceptual models with arithmetic mean values of $16 \%$ (no zones), $17 \%$ ( 3 zones) and $16.5 \%$ (5 zones). The 3-layer model (3 hydrogeological units) was considered as the best model. Although both 3-layer and 5-layer models well preserved the geological structure, the alluvium and glacial deposits which were additionally considered in the 5-layer model (Fig. 3), remained zones of small volume having very little impact in the final porosity models. Therefore the 3-layer model appeared as best to compromise in terms of resolution and simplicity of parametrization and associated computational efficiency. In this model, the MB (massive unweathered and poorly 
509 fractured mica schist $)$ had the lowest average porosity $\left(8 \times 10^{-2}\right.$, i.e. $\left.8 \%\right)$ of the 3 units followed by an 510 increase of porosity in the FB $\left(2 \times 10^{-1}\right.$, i.e. $\left.20 \%\right)$ characterized by a weathered/fractured bedrock. At

511 the top, the $\mathrm{BB}$ reached the highest porosity $\left(3 \times 10^{-1}\right.$, i.e. $\left.30 \%\right)$ considering the glacial deposits and

512 alluvium units as the areas with the higher values. The Waxman \& Smits porosity model produced

513 lower porosities than Archie's model by an order of magnitude with values for the non-structurally-

514 constrained model of $9 \times 10^{-3}$ (i.e. $0.9 \%$ ), and for the structural-constrained models of $1.3 \times 10^{-2}$ i.e.

$5151.3 \%$ (3 zones) and $1.1 \times 10^{-2}$ i.e. $1.1 \%$ (5 zones) in average. Waxman \& Smits porosities rapidly

516 decreased with depth dropping from $\mathrm{BB}\left(5 \times 10^{-2}\right.$, i.e. $\left.5 \%\right)$ by two orders of magnitude at the MB $(3 \times$

$51710^{-4}$, i.e. $0.03 \%$ ) in terms of average porosity. The unsaturated zone considered $50 \%$ for water

518 saturation $\left(\mathrm{S}_{\mathrm{w}}\right)$, increasing the porosities in the BB for both models (Archie and Waxman \& Smits),

519 this applied for the 3 scenarios (1 non-structural and 2 structural-constrained). The unsaturated zone

520 was tested applying four alternative saturations $\left(\mathrm{S}_{\mathrm{w}}=25 \%, 50 \%, 75 \%\right.$, and $\left.100 \%\right)$ producing an

521 inverse relationship between $\phi$ and $S_{w}$. Archie's model showed less dispersion of porosity values

522 showing a normal distribution within and across all the zones including the unsaturated area.

523 Contrastingly, the Waxman \& Smits model had a higher spreading of the calculated porosity with a

524 log-normal distribution across, and a normal distribution within, each of the three zones $(\mathrm{BB}, \mathrm{FB}$, and

525 MB) (Fig. 6). 

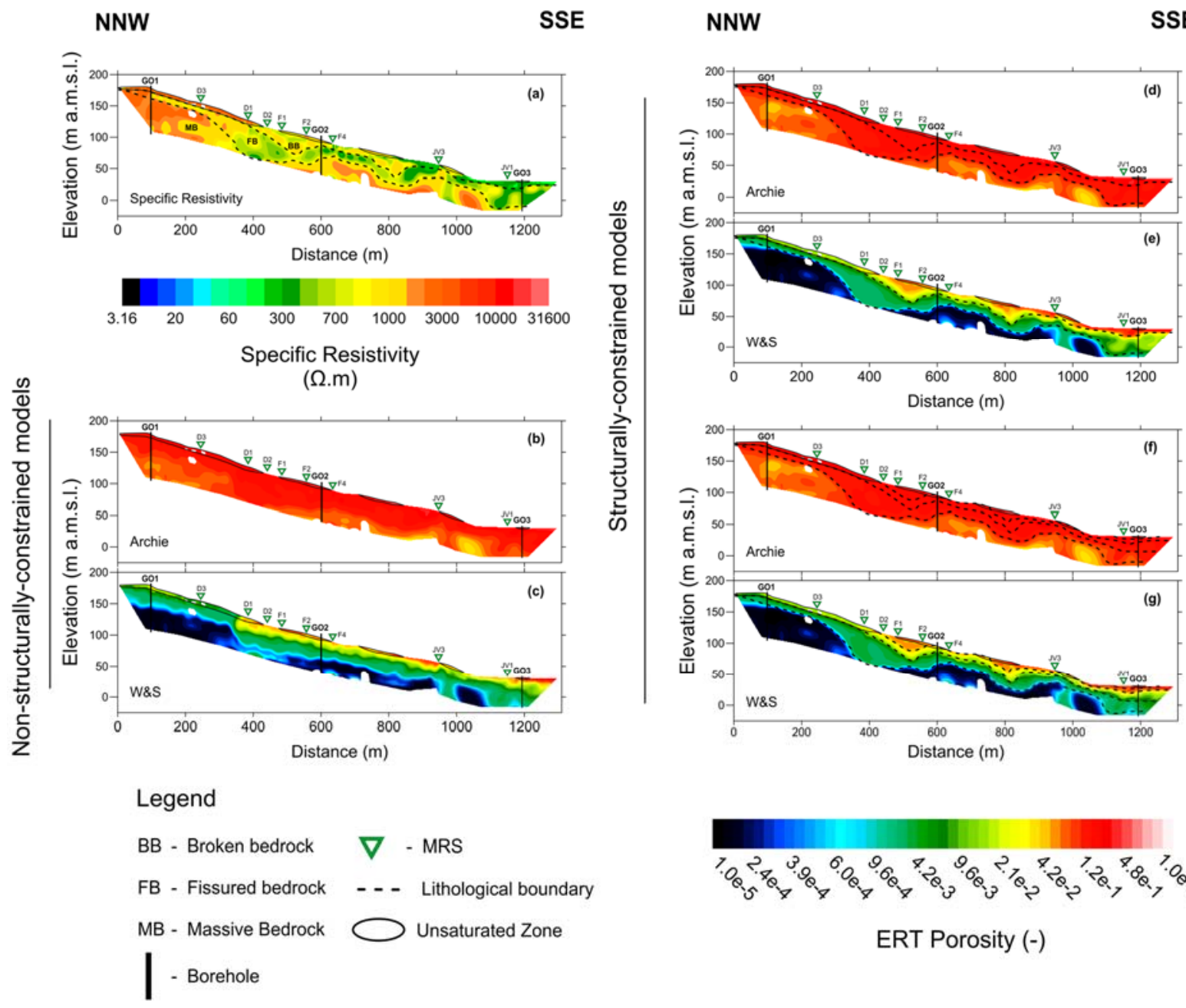

527 Figure 5. Predicted 2D spatial variations of porosity compared to original resistivity data. (a) original 528 (input) inverted ERT profile. (b-g) predicted porosity distributions for different structural constraints

529 and petrophysical models: Archie's model (b) and Waxman \& Smits model (c) no structural

530 constraint; Archie's model (d) and Waxman \& Smits model (e) with 3 structural units; Archie's model

531 (f) and Waxman \& Smits model (g) with 5 structural units. Triangles at the ground surface indicate

532 the location of MRS soundings (see section 3.5). 


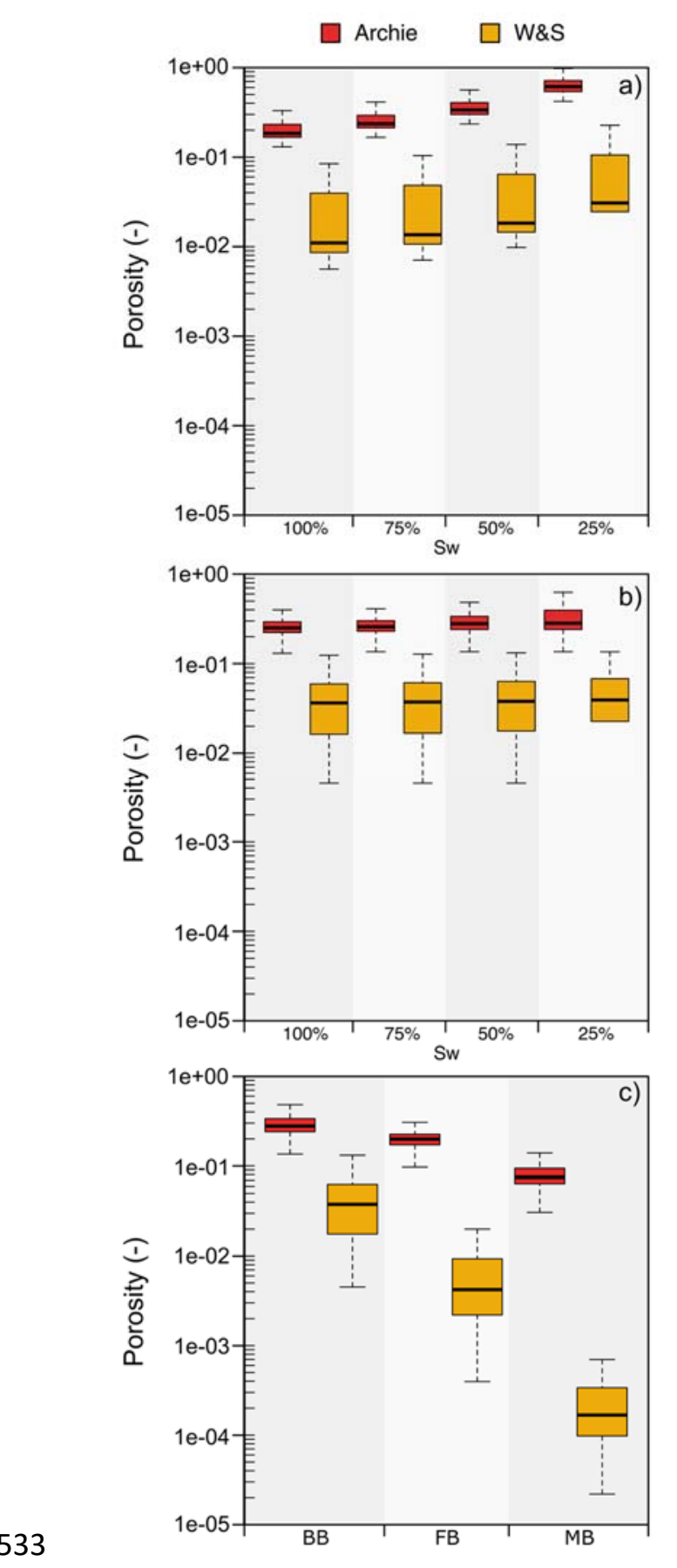

534 Figure 6. Porosity distribution per hydrogeological unit from Archie and Waxman \& Smits model. (a)

535 broken bedrock unsaturated zone considering 4 saturation values $\left(S_{w}\right) 25,50,75$ and $100 \%$, (b) entire

536 saturated and unsaturated broken bedrock unit and considering 4 values of saturation $\left(S_{w}\right)$ above the

537 water table, and c) three hydrogeological conceptual units BB, FB and MB (considering uniform 50\%

538 saturation water for the unsaturated zone. 
541 The sensitivity analysis enabled us to quantify the weight of the petrophysical parameters involved in

542 the forward modelling (Fig. 7). When using both Archie and Waxman \& Smits models, the

543 cementation exponent $(m)$ appeared as the parameter responsible for the largest sensitivity. For the

544 Archie model, a variation of $\pm 15 \%$ produced porosity changes of $\pm 26 \%$. The Waxman \& Smits model

545 was even more sensitive to $m$, i.e. for the same $\pm 15 \%$ of variation, porosity changed by $120 \%$ and -

$54668 \%$ respectively. Saturation $\left(S_{W}\right)$ was the second most sensitive parameter $(18 \%$ in a $15 \%$ increment $)$

547 in Archie's model close to that of the $m$ parameter while in the Waxman \& Smits model the uncertainty into the models.

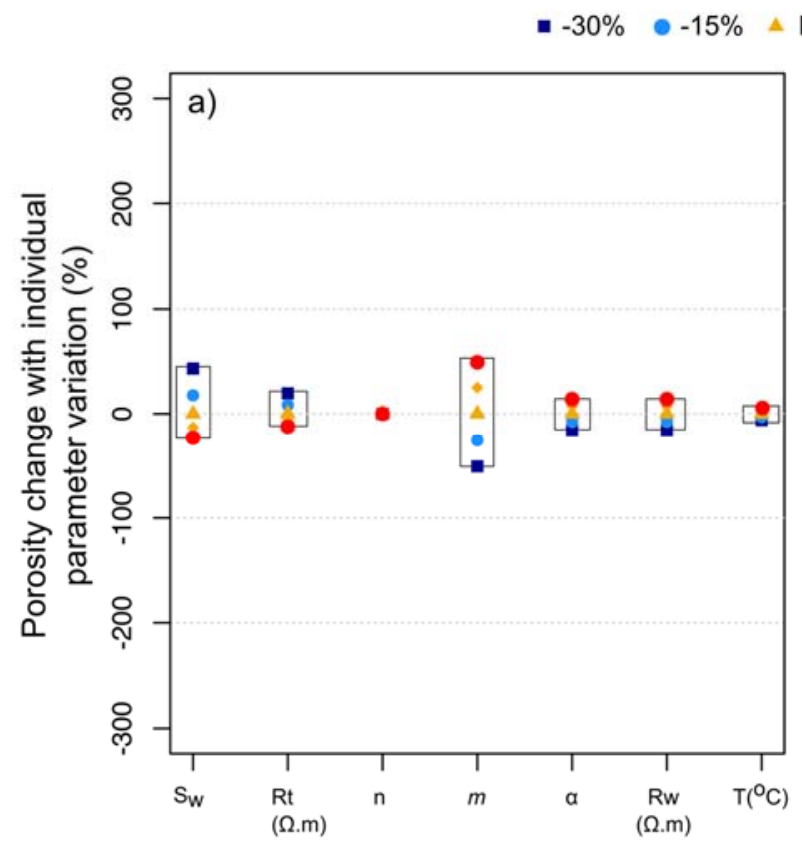

550

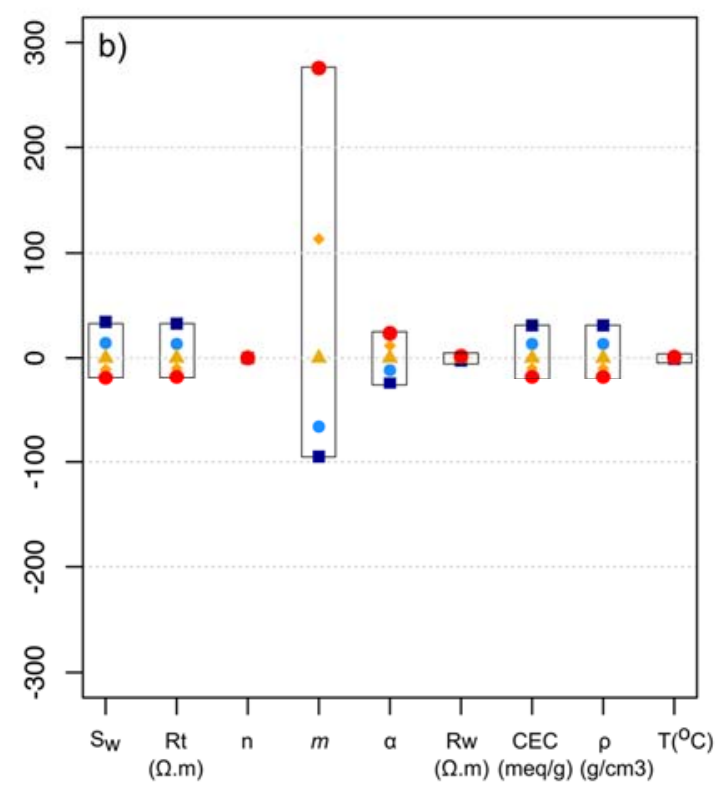

551 Figure 7. Sensitivity analysis of (a) Archie and (b) Waxman \& Smits porosity models.

553 The uncertainty analysis provided valuable information with regards to the models' accuracy. In this

554 paper, we present the relative uncertainty computed for the model with 3 hydrogeological units using the maximum and minimum possible values for each input parameter as estimated from the geological 

characteristics of the study area (Table 5). The final porosity predictions for Archie and Waxman \&

557 Smits held relative uncertainties in predicted porosities of $\pm 16 \%$ and $\pm 105 \%$ (Fig. 8) and absolute 558 uncertainties of \pm 3 and \pm 1 on average, respectively. When looking separately at average uncertainties 559 for each specific hydrogeological conceptual unit (BB, FB, MB), MB had the lowest absolute porosity 560 uncertainty (where porosity is expressed in \%) in both models (Archie $=1.44 \%$ and $\mathrm{W} \& \mathrm{~S}=0.06 \%$ ) 561 decreasing with depth (Fig. 9a). In terms of relative uncertainty, the BB unit appeared as the zone 562 with the highest values in Archie's model (22\% on average) while in Waxman \& Smits the highest 563 relative uncertainty affected the MB, amounting $180 \%$ on average and $300 \%$ locally (Fig. $9 \mathrm{~b}$ ) i.e.

564 three times the best predicted values.

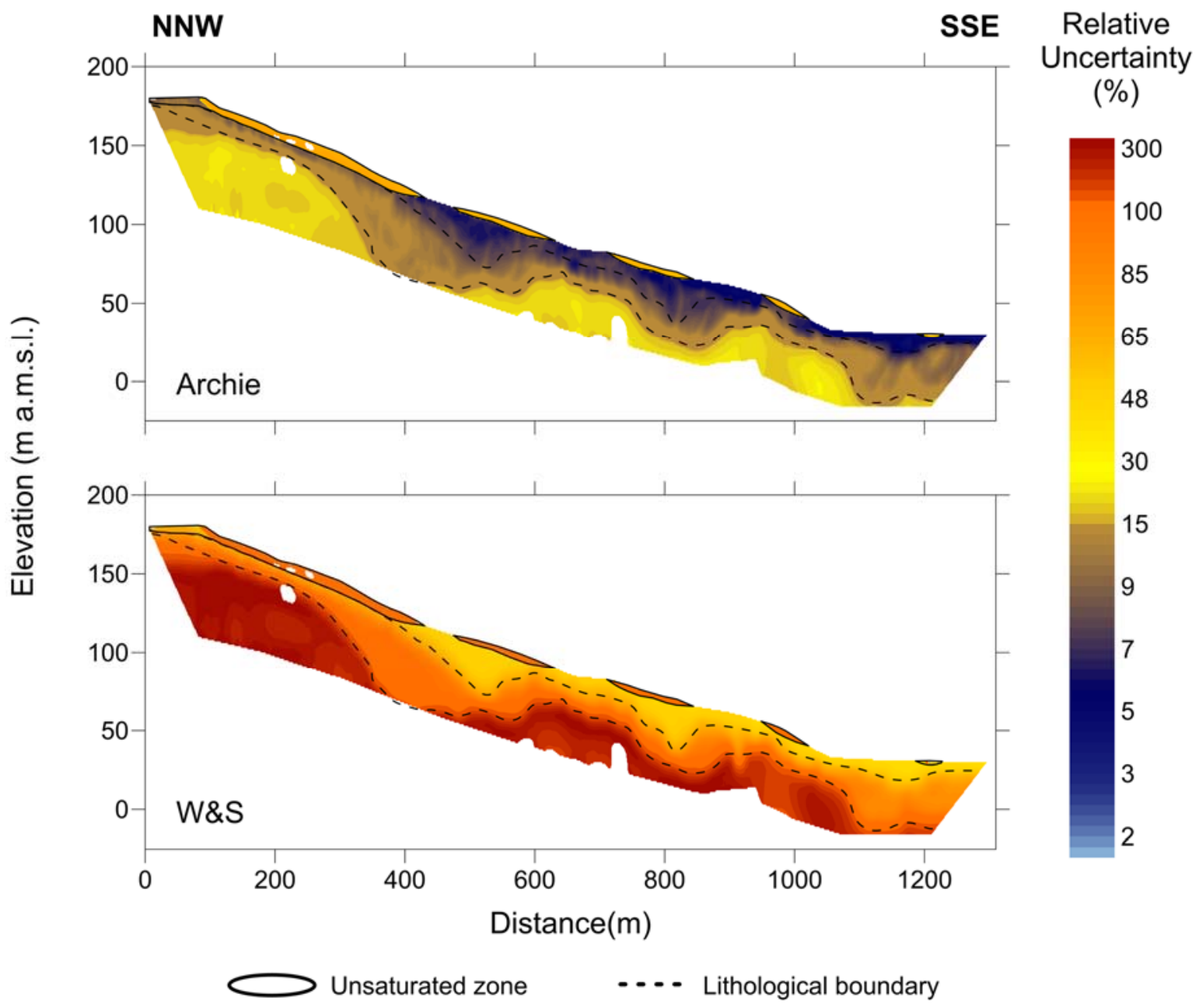

566 Figure 8. 2D relative uncertainty of Archie and Waxman \& Smits porosity models. 

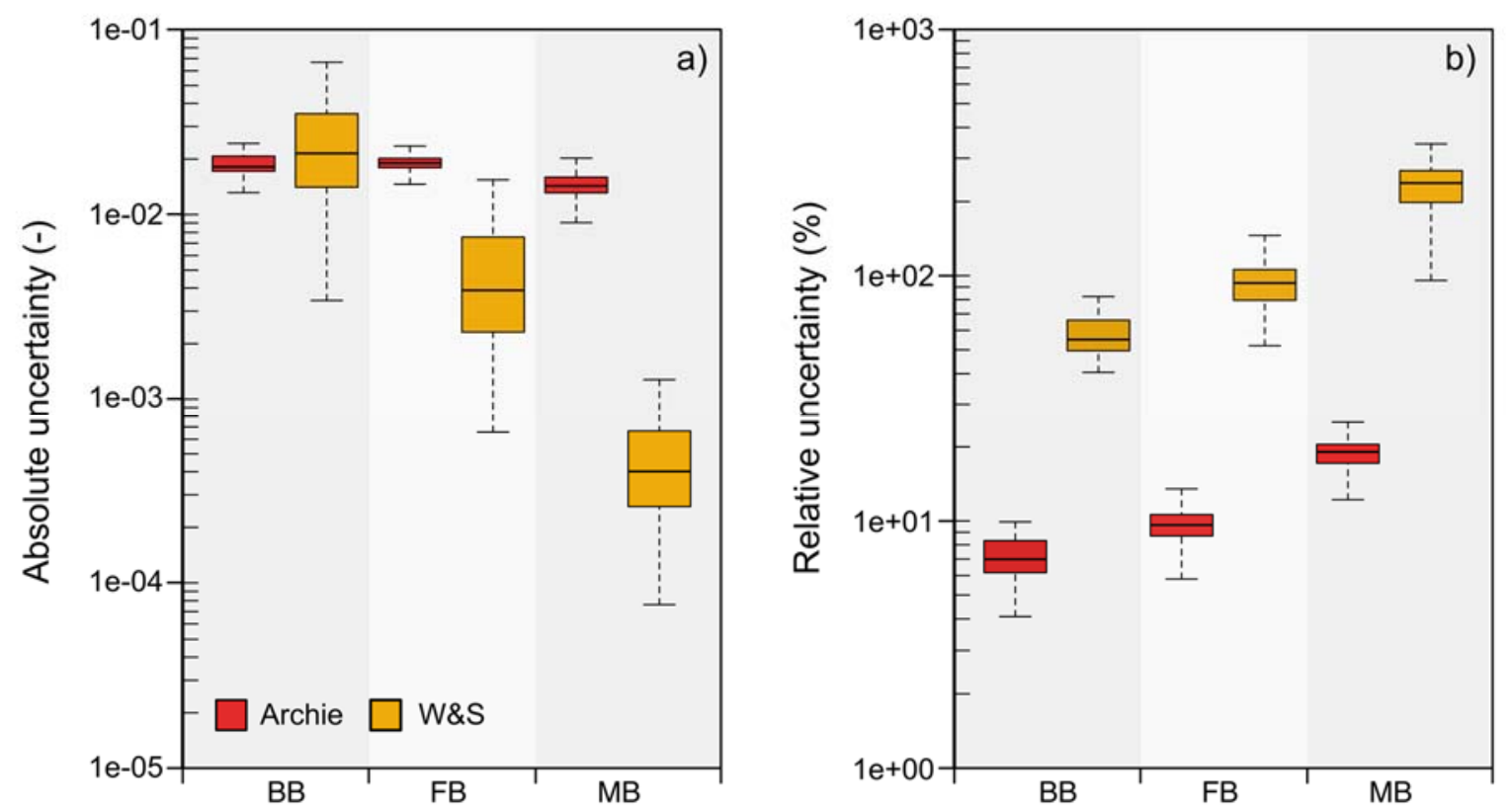

568 Figure 9. Box plots of (a) absolute and (b) relative porosity uncertainty per conceptual unit for Archie and Waxman \& Smits models.

571 The highest contributing factor to porosity uncertainty for the Archie model was the water saturation

572 ( $75 \%$ on average) while for the Waxman \& Smits model the CEC ( $87 \%$ on average) had the highest

573 contribution (Fig. 10). While the water saturation also contributed to the uncertainty in W\&S, the

574 influence was smaller compared to the uncertainty introduced by the CEC. Despite being the most

575 sensitive parameter in the model, the cementation exponent (4-7\%) did not produce as high relative

576 uncertainty as the CEC did. In addition to the other parameter uncertainties, the formation resistivity

$577\left(\mathrm{R}_{\mathrm{t}}\right)$ obtained from ERT data inversion had a relatively low uncertainty (1-21\%) and as such did not

578 impact significantly the final model uncertainty. Note that the uncertainty in the formation resistivity

579 only considers the ERT inversion errors but not the ERT measurement errors. 

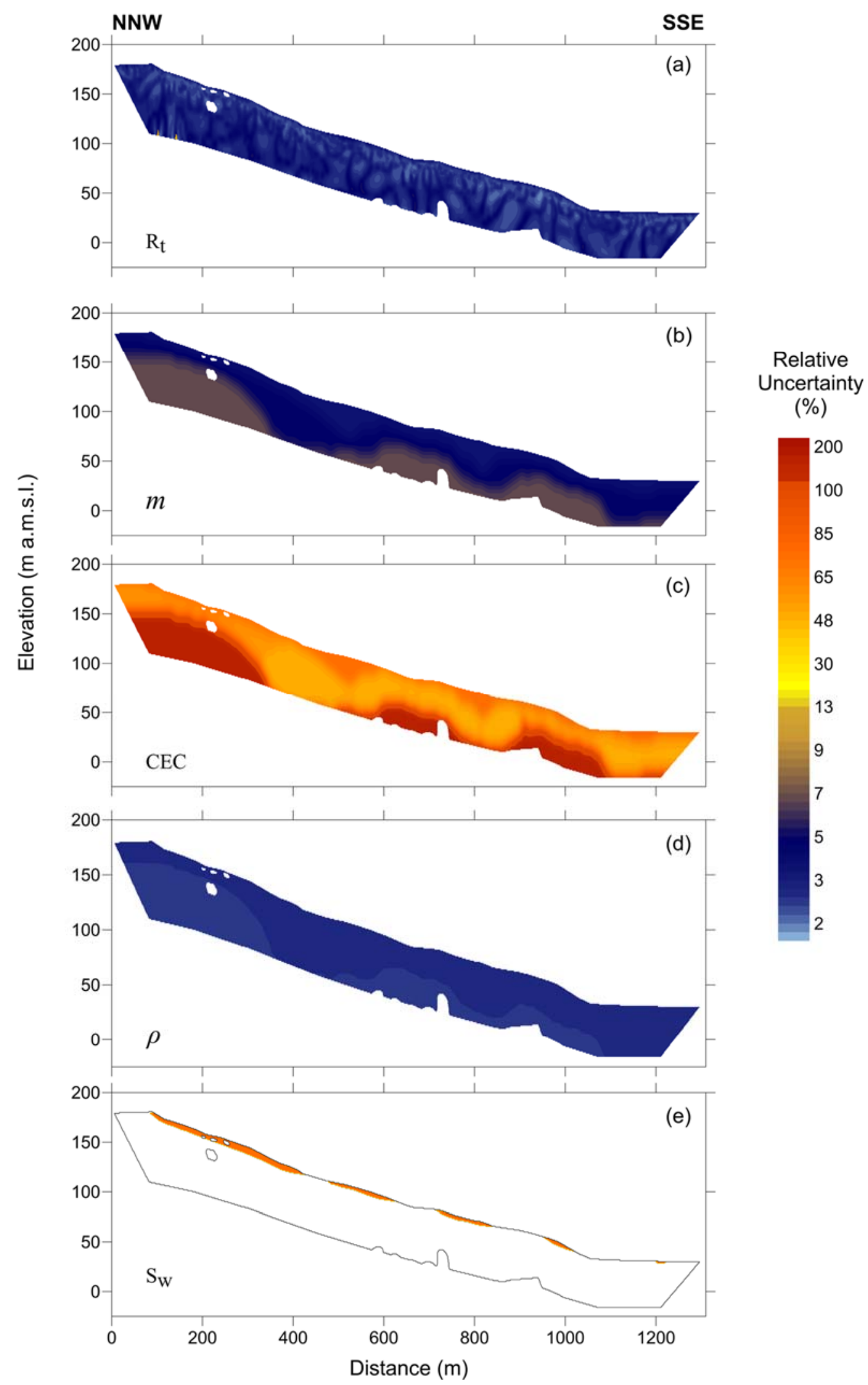

581 Figure 10. Uncertainty analysis of petrophysical models input parameters: formation resistivity $\left(\mathrm{R}_{\mathrm{t}}\right)$,

582 cementation exponent (m), cation exchange capacity (CEC), rock density $(\rho)$, and water saturation $583\left(\mathrm{~S}_{\mathrm{w}}\right)$. 
In this study, the ERT measurements errors (standard deviation of $0.13 \%$ on average) were discarded

585 from the uncertainty analysis due to being negligible compared to the inversion error $(9.6 \%)$ and model block resistivity errors ( $4 \%$ on average). The very stable, low noise, measurement conditions were to be attributed to excellent electrode coupling due to the favorable soil conditions (wet, clay-silt soils and unsaturated zone), high water table and low anthropogenic noise. In different conditions, such as drier/more resistant soils (e.g. in more arid regions), deep water table, or presence of anthropogenic noise such as metal pipes, buried fences, etc. the ERT measurements would be less stable with higher errors, which may need to be taken into account in the uncertainty analysis as the would significantly increase the uncertainty in porosity estimates.

\subsection{Model verification using independent $1 D$ water content data}

At each station, inversion of MRS measurements showed a vertical profile of the water content. The water content was compared with the boundaries of hydrogeological units identified using the ERT interpretation. It allowed to develop a correspondence between the water content value and the geological formation. Thus, the average water content (WC) was estimated with MRS as $1 \%$ in the massive bedrock, $2-3 \%$ in the fissured bedrock and in the broken bedrock ranging from 5 to $6 \%$. In the selected 8 MRS measurements, the highest WC was found in the profile F1 (1-6\%) at 480m NNW-SSE direction, characterized by a thick FB highly fractured and fully saturated. The lowest WC $(<2 \%)$ was shared by the profiles D1 and D3, at 240m NNE-SSW direction, located in a high resistivity zone (MB) with low fracture density.

The water content profiles from MRS surveys were compared with the ERT porosity models (Archie and Waxman \& Smits) extracting the data in the nearest location to each MRS survey and presented in the logarithmic scale (Fig. 11). Fig. 11 also shows the minimum and maximum models of the MRS water content and the ERT porosity models. Archie porosity values were distinguished by largely overestimating the pore space with values ranging 5-35 x 10-2 (5-35\%) i.e. about an order of magnitude (i.e. $1000 \%$ ) higher than water content obtained from MRS surveys for the broken and 
610 fissured bedrock at all locations but decreasing with depth as expected for the study area. Massive

611 bedrock estimates showed porosities ranging $1-1.5 \times 10^{-1}$ (i.e. 10-15\%), range rather expected for the

612 broken bedrock. Not accounting for the clay content in the aquifer by using Archie's law

613 overestimated the porosity of the study area where typical porosities for this geological setting were

614 widely reported are much lower (metamorphic rocks $\phi=\sim 4 \%$ ) (Earle, 2015). Waxman \& Smits

615 porosity values had a slightly better fit with MRS water content data producing consistent spatial

616 patterns at three locations. The best match occurred specifically in the profiles F1, F2, and JV1,

617 locations where the minimum and maximum values for water content and ERT-derived porosities

618 predicted the highest porosities $\left(2-6 \times 10^{-2}\right)$. In the other 5 soundings, there were significant

619 discrepancies between ERT-porosities and MRS water contents. The ERT porosity values from

620 Waxman \& Smits were higher than MRS water contents in the broken bedrock $(0-10 \mathrm{~m})$ but lower in

621 fissured and massive bedrock, overall providing lower groundwater storage values at higher depths.

622 The clay content variations in the fissured and the massive bedrock could be a reason for this behavior

623 but also the uncertainty attributed to this method (Waxman \& Smits model) that increases with depth.

D3

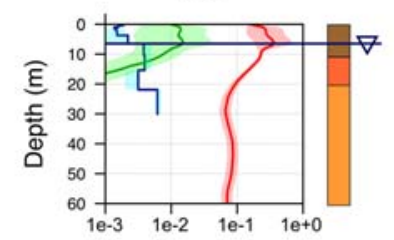

F2

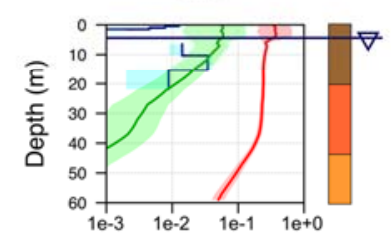

(-)
D1

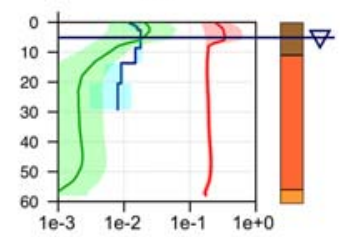

F4

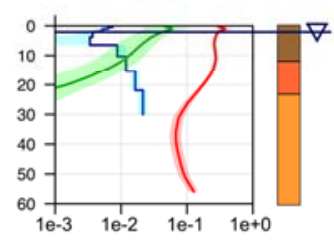

(-)
D2

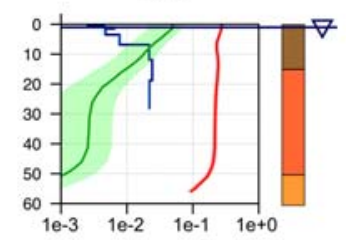

JV3

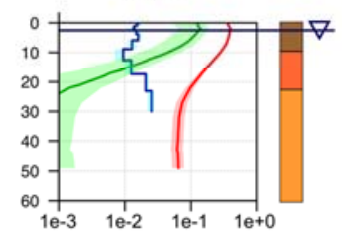

(-)
F1

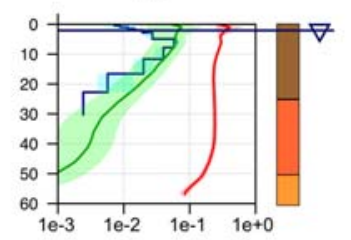

JV1

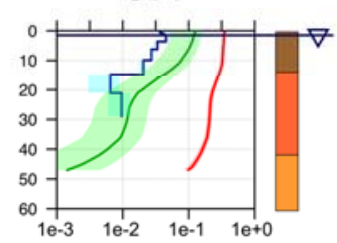

(-)

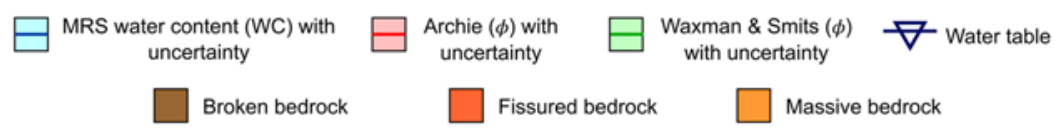

624

Figure 11. Comparison between MRS water content and ERT porosity for Archie's model and

Waxman \& Smits model (total porosity, including saturated and unsaturated porosity). 
628 Comparison of storativity data, porosity models and water content showed that Archie's porosities

629 poorly matched observed storativity values, with values always higher by an order of magnitude in all

630 the zones of the aquifer (BB, FB, and MB) and systematically out of the variability range (Fig. 12).

631 On the other hand, Waxman \& Smits porosities, displaying lower values than Archie's model,

632 matched reasonably well the storativity values, especially in the broken and fissured bedrock. WS

633 porosities in the massive bedrock were lower by an order of magnitude but close in the upper limit of 634 the variability range. MRS water content profiles generally underestimated storativity values close to 635 the surface (BB) but had a strong correlation between storativity and porosity at larger depth (FB, $r=$ 6360.97 and $\mathrm{MB}, r=0.98)$.

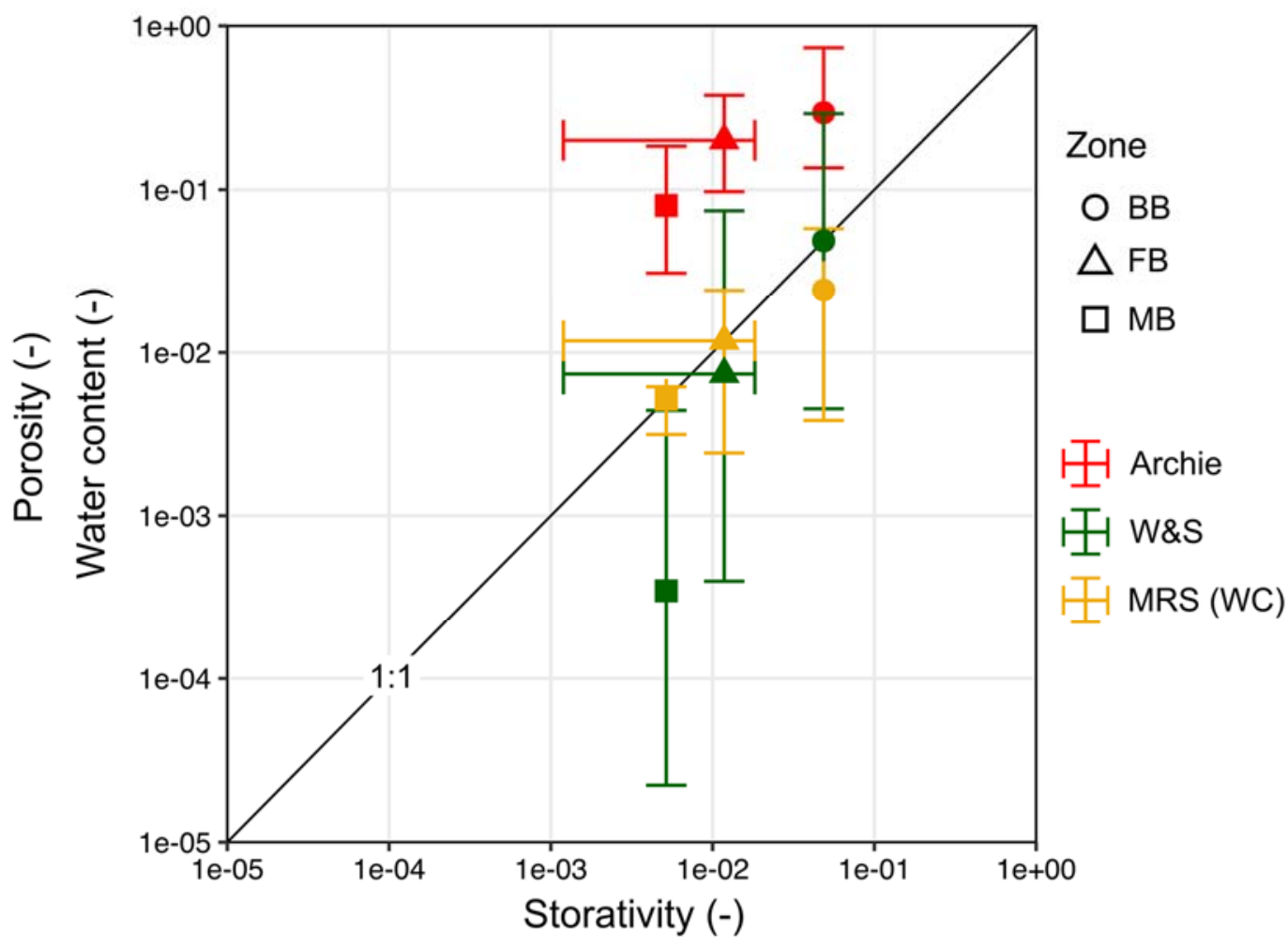

638 Figure 12. Comparison of ERT-derived porosity (Archie and Waxman \& Smits porosity models) and water content (MRS) per hydrogeological zone with their respective ranges of spatial variations (both on vertical axis), to corresponding borehole storativity values estimated from hydraulic testing (horizontal axis). 
643 The capability of resistivity methods to resolve pore space variability in a low porosity, basement

644 aquifer system with spatial variations in weathering and fracturing intensity has been explored using

645 hydrogeological and geophysical data acquired in a fractured metamorphic hard rock aquifer in

646 Ireland. This study demonstrates that Waxman \& Smits' petrophysical model is superior to Archie's

647 model because of the presence of clay minerals associated with bedrock weathering, which is

648 generalizable to most weathered/fractured basement aquifer systems. data

Interpolation of point (borehole) petrophysical data was required to provide inputs for the $2 \mathrm{D}$ petrophysical models to obtain 2D porosity distributions from 2D ERT resistivity. Both the interpolation algorithms and the integration of structural constraints based on conceptual interpretation of geophysical data as part of the interpolation had a high impact on the spatial distribution of the parameters across the study area. Combining borehole data and a geological interpretation increased the accuracy of the distribution (Boyd et al. 2019) while showing where the geological interpretations (3-zone vs 5-zone) made the higher impact. Triangular interpolation and kriging methods produced unrealistic distributions lacking geologic sense, the nearest neighbor algorithm achieved a superior spatial distribution of the data for both Archie and Waxman \& Smits models. The results exposed the fact that the absence in the interpolation of structural constraints based on hydrogeological boundaries produced spatial distributions of parameters that are geologically unrealistic as the interpolation tends to yield straight lateral continuity between boreholes, which disagreed with the structural information provided by ERT data. Constraining the models with structural boundaries is the most important tool to control the distribution of the parameters and it should be based on reliable data as is the case of this study (ERT survey). This is 
layering are incorporated as structural constraints in the interpolation of the input parameters, which produced a spatial distribution consistent with the conceptual models. As demonstrated by Chen et al. (2019) using structural constraints in the interpolation helped to achieve a much more realistic distribution of the parameters $\left(C E C, m, \rho_{g}, R_{w}\right.$, and $\left.T\right)$ that follows the geological structures of the study site than a non-structurally constrained interpolation. The difference between the two structurally-constrained models is only observable in the area surrounding GO3 borehole, where glacial deposits and alluvium are present. It is however important to note that despite being geologically more realistic, structurally-constrained interpolations also likely exacerbate the contrasts in petrophysical properties, and ultimately in the final computed porosities, between the different conceptual bedrock units as compared to a possible smoother reality.

\subsection{Importance of accounting for clay minerals and related uncertainties}

Results of this study show that Archie's porosity values $\left(1.7 \times 10^{-1}\right.$, i.e. $17 \%$, in average) are unrealistic because well above (1) expected porosities for weathered/fractured basement rock aquifers and (2) independent geophysics data (MRS) and borehole hydraulic data obtained on the site. According to Palacky (1988), hard rock aquifers are characterized by an average porosity $<4 \%$ ( $4 \mathrm{x}$ $10^{-2}$ ). Porosity ranging between $2-4 \%$ were reported by laboratory tests carried out by Bagde (2000) in three types of schists (quartz mica schist, quartz mica schist with quartz veins and biotite schist), a range of porosities that matches the ERT porosities derived in this work from the Waxman \& Smits model. Johnson (1983) reported low porosity (3\%) for metamorphic rocks, and particularly mica schists with values $<1 \%$ (Elbra et al., 2011), which is again consistent with the porosity values predicted by Waxman \& Smits. Nevertheless, the most important distinction between the two models (Archie and W\&S) is that the latter accounts for the effect of clays minerals, which significantly contribute to the measured resistivity similarly as pore fluid. In this study, Waxman \& Smits model shows that the clay in the bedrock aquifer reduces the porosity predicted from Archie's model by an order of magnitude, decreasing with depth as fracture density reduces. 
694 Sensitivity and uncertainty analysis were only performed for the 3-units conceptual model for both

695 Archie and Waxman \& Smits. The low variability of the results and small areas that represents the

696 glacial deposits and alluvium which were accounted for in the 5-unit conceptual model do not have a

697 considerable influence in the final porosity models. The sensitivity analysis demonstrates that Archie

698 is less affected by variations in the input petrophysical parameters than Waxman \& Smits. Despite

699 both being more sensitive to changes in the cementation exponent (Chen \& Fang, 1986), Waxman \&

700 Smits overall has higher sensitivity due to the additional factors in the equation accounting for the

701 clay content (CEC), a product of the bedrock weathering. Therefore, to build an accurate model, it is

702 necessary to well constrain the estimates for the cementation exponent for both models and the

703 influence of clay for Waxman \& Smits in order to reduce uncertainty in the results. In the present

704 analysis, the large uncertainty relating to clay properties (CEC) has a large impact on the porosity

705 estimate uncertainty in the Waxman \& Smits model, whereas, with the Archie model, all parameters

706 have an equivalent contribution to porosity uncertainty. At shallow depth within the unsaturated zone

$707(<10 \mathrm{~m})$, high uncertainty in the values of saturation also largely contributed to porosity uncertainty

708 for both models. However, as the unsaturated zone is relatively thin in the study area, it did not have a

709 large impact on the overall relative uncertainty.

5.3. Reconciling the different types of storage properties to which the different methods (ERT, MRS, hydraulic tests) are sensitive

The predicted 2D porosity distributions were further verified through comparison to independent subsurface water content data provided by MRS surveys (Legchenko et al., 2017) (Fig. 11). The water content estimates provided by MRS are considered to reflect a part of the effective saturated porosity of a reservoir corresponding to mobile water (close to the storativity) (Legchenko et al., 2002; Vouillamoz et al., 2012), whereas resistivity-derived porosities are widely considered as reflecting the total saturated porosity of the aquifer including mobile and bound water (Turesson, 2006). This

719 implies that the ERT-porosity estimate cannot be expected to be lower than the storativity, and the MRS water content estimates can be equal or lower than the ERT-derived porosities. Johnson (1983) 
reported from laboratory experiments implemented on several samples of metamorphic rocks (mica schist, muscovite schists, gneiss, etc.) an average total porosity $35 \%$ higher than the connected effective porosity. The Waxman \& Smits model produced overall porosity values closer to the MRS water content estimates, though generally higher by about $40 \%$ on average, which is consistent with the findings by Johnson (1983). The agreement between W\&S and MRS porosities is particularly good for soundings F1, F2, and JV1 (Fig. 11). These specific locations are characterized by areas with relatively higher porosity $(>4 \%)$ and thicker BB $(12-25 \mathrm{~m})$ and $\mathrm{FB}(10-30 \mathrm{~m})$ units associated with regional fracture systems (Comte et al., 2012a, 2019). At larger depths (MB) for these locations, the uncertainty of MRS water content (but also of ERT-derived porosity) increased and the correlation between the two is poor, with ERT porosity significantly higher than MRS water content. This deviation could be attributed to the decrease in fracture connectivity with depth in the massive bedrock resulting in a more rapid decrease in effective porosity and/or storativity versus total porosity and associated loss of sensitivity of the MRS method (Legchenko et al., 2002). In the other 5 profiles (D1, D2, D3, F4, and JV3), there are some incongruities between the ERT-porosities and MRS water content. These locations were further away from deeper weathered/fractured zones and characterized by overall lower water content close to or lower than $1 \%$. There, MRS water content appeared relatively constant or increasing with depth and was much higher than ERT-derived porosities. However, the MRS method is known to rapidly lose sensitivity below $1 \%$ water content where data inversion becomes unreliable (Legchenko et al., 2006). Similarly, ERT-derived porosities could be underestimated in these areas particularly for the massive bedrock due to the ERT inversion tending to overestimate resistivities below conductive material (FB). Both could explain the large deviation at depth at these locations.

The overall comparison is consistent with current knowledge that resistivity-derived porosity provides a close estimate of total porosity (Ellis and Singer, 2007; He et al., 2018) and as such should be higher than or equal to the aquifer's effective groundwater storage (storativity). For most of our presented results, the ERT-derived porosities are indeed equal to or higher than the MRS water content known to be reflective of aquifer storativity rather than total saturated porosity. More specifically the 
porosities obtained from the application of the Waxman \& Smits model are consistent with the expected difference between effective and total porosity in fractured rocks of about a factor of 2 (Aguilera and Aguilera, 2003; Tiab et al., 2006); whereas Archie's model is shown to massively overestimate this difference by a factor of 10 (an order of magnitude) demonstrating that clay minerals cannot be neglected in the analysis of similar metamorphic rock aquifer settings.

Further comparison of the results with actual aquifer storativity values previously obtained from hydraulic testing at borehole locations by Comte et al. (2012a) confirmed Archie's model poor predicting ability of storage properties. Waxman \& Smits porosities in contrast show a good match with storativities obtained in the broken and fissured bedrock (the weathered-fractured part of the system). This would suggest either that the porosity derived from this model in this upper part of the bedrock is reflective of the aquifer's effective storage capacity rather than the total porosity (including bound and unconnected groundwater), or that storativity and total porosity are not significantly different in these horizons. However, it is also likely that storativity values obtained from hydraulic testing are providing an overestimation of the actual aquifer storativity due to being representative of a small area abound the boreholes (because of the low pumping rates applicable for hydraulic testing such low productivity hydrogeological environment) affected by locally increased porosity associated to the downhole hammer drilling technique (Kirlas and Katsifarakis, 2020; Pongmanda and Suprapti, 2020). Such artificially increased porosity and storativity would have relatively more effect on deeper (more massive) than shallower bedrock horizons. In the MB specifically, WS-derived porosities appeared much lower than storativity values. This difference could indeed be due to; (1) as also discussed above when comparing ERT porosity and MRS water content, an underestimation of porosity in the MB due to overestimation of inverted resistivities below the lower resistivity FB together with the uncertainty attributed to the selection of $m$ for the MB; or (2) overestimated storativities values from hydraulic testing in the MB (artificially increased porosity in the borehole walls, and local preferential pathways possible due to the large uncased interval characterizing MB boreholes). MRS water content on another hand is relatively close to storativity values in the FB and MB. Based on discussions above, the good match for MB might be coincidental due to both (1) a 
possible overestimation of MRS water content in the MB, where MRS profiles often showed illogical increasing water content with depth likely resulting from lack of accuracy of the MRS inversions (Legchenko et al., 2017) for low water content values; (2) a possible overestimation of storativity from hydraulic tests in the MB. MRS water content also appeared slightly lower than storativities in the BB. Overall, it can be reasonably concluded that the WS porosity provides an upper estimate of groundwater storage in the weathered/fractured aquifer units (BB and FB).

\subsection{Limitations associated to field measurements and geophysical inversion errors and wider} application to $3 D$ heterogeneous hard rock aquifer settings

Modelling petrophysical properties is a challenging process. The high heterogeneity of weathered/fractured aquifers complicates any attempt to estimate properties, as in this study porosity (Paillet and Reese, 2000; Doetsch et al., 2010; Whitman and Yeboah-Forson, 2015). This study encountered limitations typical to field studies in heterogeneous subsurface systems, attributed to: (1) uncertainties in point-based measurements of parameters used to parameterize the porosity models (cementation exponent and clay volumes); (2) uncertainty and representativity issues relating to storativities values obtained from low rate hydraulic testing used for verification, which are likely overestimations increasing with depth (i.e. with decreasing porosity) (3) poor spatial density of borehole data providing the petrophysical input parameters and storativity verification data; (4) spatial distortions and errors relating to inverted geophysical data used as model input parameters (different averaging between ERT and MRS; ERT use 2-D inversion and MRS 1-D inversion, both in 3-D geological settings); and (5) possible additional uncertainty attributed to the geophysical measures errors (noise) prior to geophysical inversion (negligible in this work but potentially significant in other, more noisy conditions, e.g. drier/more resistant soils and anthropogenic noise). Addressing some of these limitations would reduce uncertainty, providing more accurate values in porosity models. Acquiring more data does not always translate into better results, but in this study having additional borehole data in a reduced spacing would help to control the spatial distribution and increase the resolution of the models, along with providing additional verification dataset. 
802

803

804

805

806

807

808

809

810

811

812

813

814

815

816

817

818

The one- and two- dimensionalities of data and models used might be insufficient in some strongly three-dimensional settings, which would require 3D ERT acquisition. In this case study, however, previous hydrogeological studies (Comte et al., 2012a, 2019) suggest lateral continuity of structures perpendicular to the ERT profile justifying the use of 2D ERT data. Similarly, more confident validation with borehole and MRS data would be obtained from denser 2D borehole coverage and 2D MRS acquisition and inversion, with 3D borehole and 3D MRS analyses required for other strongly $3 \mathrm{D}$ basement settings. The approach developed overall is applicable to most basement aquifer settings and bedrock lithologies subject to a certain degree of weathering. Some challenges would arise in; (1) deeply weathered, argillized basement rocks such as clay rich metamorphic rocks subject to deep tropical weathering, where ERT inversion would be inaccurate below highly conductive weathering clays (Bazin and Pfaffhuber, 2013) resulting in poor delineation of weathered vs. fractured vs. massive bedrock and inaccurate quantification of storage properties (2) unweathered, poorly fractured basement rocks such as crystalline rocks subject to glacial erosion preventing development of significant weathering and weathering-aided open fracture networks. Nevertheless, the flexibility of the ERT methods allowing adjusting its resolution to the expected scale of heterogeneity (Chambers et al., 2010; Cheng et al., 2019) makes it a useful technique for a range of heterogeneous basement settings from local-scale variations of fracture density and weathering to regional fault zones.

The higher uncertainty in the approach is attributed to the clay content of the aquifer with limited data from boreholes to directly estimate mineralogy and clay volume spatial variability in the subsurface with high accuracy. Implementing an alternative geophysical method (e.g., induced polarization) providing additional constraints on clay content and/or electrical properties could improve the outcome of the Waxman \& Smits model (Binley et al., 2015; Revil et al., 2019).

\subsection{Transferability of methods and findings}

Although the methodology developed in this study was applied to a specific location, the approach can be extended to most basement rock aquifer settings. All basement rocks (intrusive igneous and 
metamorphic rocks such as gneiss, granite, schist) are affected by carriable degree of weathering and

829 fracturing responsible to a weathering profile as described in Fig. 2, and more generically by e.g.

830 Lachassagne et al. (2011), which is globally ubiquitous. A possible exception are basement rocks

831 freshly exposed after deep glacial erosion, which may have been completely removed of their

832 weathering profile at the exception of the bottommost fresh massive bedrock. Electrical (e.g. ERT)

833 and electromagnetic geophysical methods are well-established techniques effective to delineate these

834 weathering patterns in various basement rock types and climate setting (Beauvais et al., 2004; Undul

835 et al., 2011; Belle et al., 2019). Consequently, the present approach may be potentially implemented

836 in most basement settings. In addition, the approach can also be applied to any other resistivity

837 map/models obtained from other electromagnetic survey methods e.g. frequency and time domain

838 electromagnetics FEM/TEM, magneto-telluric MT (Descloitres et al., 2000; El-Kaliouby, 2009). This

839 includes data from airborne TEM whose popularity is rapidly increasing for large-scale

840 hydrogeological mapping including in basement rocks (Chandra et al., 2019). A limitation of the

841 approach however is the need for data on bedrock clay content and mineralogy, and importantly their

842 spatial variations, necessary for CEC estimation required for the Waxman \& Smits model. While

843 some data may be obtained from literature for the considered site or extrapolated from other regions,

844 additional in situ investigations are recommended. This include analysis of core sample and borehole

845 geophysics to estimate vertical clay properties variation along the weathering profile. Alternative

846 geophysical methods (e.g. induced polarization) may profile information on clay content and CEC

847 (Revil et al., 2019). The present work also shows that the MRS method (distributed vertical sounding

848 or tomography) could also be used to calibrate either the Waxman and Smits model, or directly the

849 porosity/water content, within or across lithotypes, for subsequent large-scale porosity modelling

850 using high resolutions resistivity data.

\section{6. Conclusions}

853 This study explored the qualitative and quantitative the use of electrical resistivity tomography to 854 assess groundwater storage variations at high spatial resolution in a weathered/fractured basement 
rock aquifer in Ireland, using the two most commonly applied petrophysical models to relate resistivity to porosity: Waxman and Smits (1968), which accounts for the influence of clay minerals produced by weathering processes, and Archie (1942), which disregards clays.

Results show that ERT was capable of qualitatively delineating at high (2D vertical) spatial resolution the variability in porosity associated to depth-decreasing weathering and fracturing and as well as local deeper weathered/fracture zones. On a quantitative level, the use of the WS model with ERT data provided a reasonable upper-bound estimate of storage properties values (storativities) in the weathered/fractured parts of the bedrock ( $\sim 5$ to $50+\mathrm{m}$ in the studied area). These values were shown to range across 2 to 3 orders of magnitude from typically $1-10 \%$ in the uppermost weathered 'broken bedrock' to $0.1-1 \%$ in the underlying fissured bedrock, and further down by another order of magnitude lower in the deep massive bedrock. These values were broadly consistent with independent storativities estimates for the weathered/fractured aquifer levels provided by magnetic resonance soundings (at 8 locations) and borehole hydraulic testing ( 9 data including 3 different depths at 3 sites). These values are consistent with reported typical values for hard rock settings. This work further resolves the large spatial (including depth) variability in storage properties that may be encountered in basement aquifer settings, at high spatial resolution and with reasonable uncertainties, i.e. an overall exponential decrease in storativity with depth and with distance to valley bottom to which superimposes smaller, meter to 100 -meter scale, variability related to deep weathering corridors associated with fault lines. Some inconsistencies however were found in the storativities values provided by all three methods in the deep massive bedrock owing to limitations and inaccuracies specific to each method, which prevented any reliable quantification in this deepest unit.

More specifically, the study highlighted the inadequacy of Archie's model to derive porosity from resistivity in weathered/fractured aquifers, for which Waxman and Smits model, which accounts for the major effect of clay mineral on resistivity data, must be preferred.

The choice of the method of interpolation of point (borehole) input parameters for the petrophysical models, along with the use of structural constraints in the interpolation based on hydrogeological conceptual interpretation of ERT data, also proved crucial to obtaining realistic porosity distributions. 
882 Both petrophysical models were found to be highly sensitive to the cementation factor, however,

883 because of its reported low variability for basement settings this did not have the highest impact on

884 porosity prediction uncertainties. Instead, the clay content and CEC (for WS model) were responsible

885 for the largest source of uncertainty in predicting porosity from resistivity highlighting the need for in

886 situ data on bedrock mineralogy (including clay content and minerals). Relative uncertainty increased

887 in two directions, vertically with depth, and laterally from downhill to uphill, and this concurrently to

888 porosity decrease due to increasing relative importance of uncertainties of cementation factor and in

889 clay properties.

890 This study also provides an example of how the combination of near surface geophysical methods

891 (here ERT and MRS), can contribute to achieving a better interpretation of the storage properties

892 values and spatial variability of low storage weathered/fractured hard rock aquifers. The approach can

893 be extended to resistivity imaging methods in a wide sense, i.e. not only ERT but by extension also

894 electromagnetic methods (e.g. frequency/time domain EM) that yield resistivity models, which can be

895 used with WS to derive porosity models.

896 Characterizing hard rock aquifers remains challenging, and the limited number of published in situ

897

898

899

900

901

902

903

904

905

906

907 quantitative research suggests that more work needs to be done to understand these groundwater resources and specifically the in situ spatial variability of hydrogeological properties. Estimating spatial porosity patterns is a crucial step in quantifying the distribution and volume of groundwater resources in hard rock aquifers required to support sustainable potable water supplies, agriculture/livestock farming, environmental flows and groundwater dependent ecosystems, geothermal applications, etc., but also to predict the response of these resources to short and long term changes in climate, including climate variability and human exploitation.

\section{Acknowledgments}

We thank the National Council of Science and Technology and Secretariat of Energy of México (CONACYT-SENER) for funding this research, and the Geological Survey of Ireland and MSc 
students at Queen's University of Belfast for assistance in data collection. We appreciate the insightful and constructive comment by P. Lachassagne and two anonymous reviewers which contributed to improve the manuscript.

\section{References}

Abdulaziz, A.M., Hurtado, J.M., Faid, A., 2012. Hydrogeological characterization of Gold Valley: an investigation of precipitation recharge in an intermountain basin in the Death Valley region, California, USA. Hydrogeol. J. 20, 701-718. https://doi.org/10.1007/s10040-012-0840-8

Aguilera, M.S., Aguilera, R., 2003. Improved models for petrophysical analysis of dual porosity reservoirs. Petrophysics 44, 15.

Aguilera, R., 2008. Effect of fracture dip and fracture tortuosity on petrophysical evaluation of naturally fractured reservoirs. Pet. Soc. Can. 8 .

Aguilera, R., 1976. Analysis of naturally fractured reservoirs from conventional well logs. J. Pet. Technol. 11.

Ahmed, S., Jayakumar, R., Salih, A., 2008. Groundwater dynamics in hard rock aquifers: sustainable management and optimal monitoring network design. Springer, Dordrecht, The Netherlands.

Archie, G.E., 1942. The electrical resistivity log as an aid in determining some reservoir Characteristics. Trans. AIME 146, 54-62. https://doi.org/10.2118/942054-G

Arps, J.J., 1953. The effect of temperature on the density and electrical resistivity of sodium chloride solutions. J. Pet. Technol. 5, 17-20. https://doi.org/10.2118/953327-G

Bagde, M.N., 2000. An investigation into strength and porous properties of metamorphic rocks in the Himalayas: A case study. Geotech. Geol. Eng. 18, 209-219.

https://doi.org/10.1023/A:1026518616345 
Balaman, Ş.Y., 2019. Uncertainty issues in biomass-based production chains, in: Decision-making for

932 biomass-based production chains. Elsevier, pp. 113-142. https://doi.org/10.1016/B978-0-12-814278-

$933 \quad 3.00005-4$

934 Bazin, S., Pfaffhuber, A.A., 2013. Mapping of quick clay by electrical resistivity tomography under 935 structural constraint. J. Appl. Geophys. 98, 280-287. https://doi.org/10.1016/j.jappgeo.2013.09.002

936 Beauvais, A., Ritz, M., Parisot, J.-C., Bantsimba, C., Dukhan, M., 2004. Combined ERT and GPR

937 methods for investigating two-stepped lateritic weathering systems. Geoderma 119, 121-132.

938 https://doi.org/10.1016/j.geoderma.2003.06.001

939 Belle, P., Lachassagne, P., Mathieu, F., Barbet, C., Brisset, N., Gourry, J.-C., 2019. Characterization 940 and location of the laminated layer within hard rock weathering profiles from electrical resistivity 941 tomography: implications for water well siting. Geol. Soc. Lond. Spec. Publ. 479, 187.

942 https://doi.org/10.1144/SP479.7

943 Bibi, I., Icenhower, J., Niazi, N.K., Naz, T., Shahid, M., Bashir, S., 2016. Clay Minerals, in:

944 Environmental Materials and Waste. Elsevier, pp. 543-567. https://doi.org/10.1016/B978-0-12-

$945 \quad 803837-6.00021-4$

946 Binley, A., Hubbard, S.S., Huisman, J.A., Revil, A., Robinson, D.A., Singha, K., Slater, L.D., 2015.

947 The emergence of Hydrogeophysics for improved understanding of subsurface processes over

948 multiple scales. Water Resour. Res. 51, 3837-3866. https://doi.org/10.1002/2015WR017016

949 Boyd, D.L., Walton, G., Trainor-Guitton, W., 2019. Quantifying spatial uncertainty in rock through 950 geostatistical integration of borehole data and a geologist's cross-section. Eng. Geol. 260, 105246. https://doi.org/10.1016/j.enggeo.2019.105246

952 Butler, J.J., 2005. Hydrogeological methods for estimation of spatial variations in hydraulic 953 conductivity, in: Rubin, Y., Hubbard, S.S. (Eds.), Hydrogeophysics. Springer, Dordrecht, The 954 Netherlands, pp. 23-58. https://doi.org/10.1007/1-4020-3102-5_2 
955 Caulfield, J., Chelliah, M., Comte, J.-C., Cassidy, R., Flynn, R., 2014. Integrating petrography,

956 mineralogy and hydrochemistry to constrain the influence and distribution of groundwater

957 contributions to baseflow in poorly productive aquifers: Insights from Gortinlieve catchment, Co.

958 Donegal, NW Ireland. Sci. Total Environ. 500-501, 224-234.

959 https://doi.org/10.1016/j.scitotenv.2014.08.105

960 Chambers, J.E., Wilkinson, P.B., Wealthall, G.P., Loke, M.H., Dearden, R., Wilson, R., Allen, D.,

961 Ogilvy, R.D., 2010. Hydrogeophysical imaging of deposit heterogeneity and groundwater chemistry

962 changes during DNAPL source zone bioremediation. J. Contam. Hydrol. 118, 43-61.

963 https://doi.org/10.1016/j.jconhyd.2010.07.001

964 Chandra, S., Auken, E., Maurya, P.K., Ahmed, S., Verma, S.K., 2019. Large scale mapping of

965 fractures and groundwater pathways in crystalline hardrock by AEM. Sci. Rep. 9, 398.

966 https://doi.org/10.1038/s41598-018-36153-1

967 Chaudhuri, A., Sekhar, M., Descloitres, M., Godderis, Y., Ruiz, L., Braun, J.J., 2013. Constraining

968 complex aquifer geometry with geophysics (2-D ERT and MRS measurements) for stochastic

969 modelling of groundwater flow. J. Appl. Geophys. 98, 288-297.

970 https://doi.org/10.1016/j.jappgeo.2013.09.005

971 Chen, H.C., Fang, J.H., 1986. Sensitivity analysis of the parameters in Archie's water saturation 972 equation. Log Anal. 27, 6.

973 Chen, Y., Chen, X., Wang, Y., Zu, S., 2019. The interpolation of sparse geophysical data. Surv.

974 Geophys. 40, 73-105. https://doi.org/10.1007/s10712-018-9501-3

975 Cheng, Q., Tao, M., Chen, X., Binley, A., 2019. Evaluation of electrical resistivity tomography (ERT)

976 for mapping the soil-rock interface in karstic environments. Environ. Earth Sci. 78, 439.

977 https://doi.org/10.1007/s12665-019-8440-8 
978 Christidis, G.E., 2010. Industrial Clays, in: Ferraris, G., Christidis, G.E. (Eds.), Advances in the

979 Characterization of Industrial Minerals. European Mineralogical Union, pp. 341-414.

980 https://doi.org/10.1180/EMU-notes.9.9

981 Comte, J.-C., Cassidy, R., Nitsche, J., Ofterdinger, U., Pilatova, K., Flynn, R., 2012a. The typology of

982 Irish hard-rock aquifers based on an integrated hydrogeological and geophysical approach.

983 Hydrogeol. J. https://doi.org/10.1007/s10040-012-0884-9

984 Comte, J.-C., Cassidy, R., Ofterdinger, U., Wilson, C., Nitsche, J., 2012b. A combined Dipole-

985 Dipole/multi-Gradient ERT array optimised for the hydrogeological characterisation of hard rock

986 aquifers. Presented at the International Conference of Groundwater in Fractured Rocks, Prague, Cezch

987

Republic. https://doi.org/10.13140/2.1.1420.4169

988

Comte, J.-C., Ofterdinger, U., Legchenko, A., Caulfield, J., Cassidy, R., Mézquita González, J.A., 2019. Catchment-scale heterogeneity of flow and storage properties in a weathered/fractured hard rock aquifer from resistivity and magnetic resonance surveys: implications for groundwater flow paths and the distribution of residence times. Geol. Soc. Lond. Spec. Publ. 479, 35-58.

992 https://doi.org/10.1144/SP479.11

Day-Lewis, F.D., Slater, L.D., Robinson, J., Johnson, C.D., Terry, N., Werkema, D., 2017. An overview of geophysical technologies appropriate for characterization and monitoring at fracturedrock sites. J. Environ. Manage. 204, 709-720. https://doi.org/10.1016/j.jenvman.2017.04.033

Descloitres, M., Guérin, R., Albouy, Y., Tabbagh, A., Ritz, M., 2000. Improvement in TDEM sounding interpretation in presence of induced polarization. A case study in resistive rocks of the Fogo volcano, Cape Verde Islands. J. Appl. Geophys. 45, 1-18. https://doi.org/10.1016/S09269851(00)00015-X

1000 Descloitres, M., Ruiz, L., Sekhar, M., Legchenko, A., Braun, J.-J., Mohan Kumar, M.S., 1001 Subramanian, S., 2008. Characterization of seasonal local recharge using electrical resistivity tomography and magnetic resonance sounding. Hydrol. Process. 22, 384-394. https://doi.org/10.1002/hyp.6608 
1004

1005

1006

1007

1008

1009

1010

1011

1012

1013

1014

1015

1016

1017

1018

1019

1020

1021

1022

1023

1024

1025

1026

1027

Dewandel, B., Lachassagne, P., Zaidi, F.K., Chandra, S., 2011. A conceptual hydrodynamic model of a geological discontinuity in hard rock aquifers: Example of a quartz reef in granitic terrain in South India. J. Hydrol. 405, 474-487. https://doi.org/10.1016/j.jhydrol.2011.05.050

Doetsch, J., Linde, N., Coscia, I., Greenhalgh, S.A., Green, A.G., 2010. Zonation for 3D aquifer characterization based on joint inversions of multimethod crosshole geophysical data. Geophysics 75, G53-G64. https://doi.org/10.1190/1.3496476

Dolcater, D.L., Jackson, M.L., Syers, J.K., 1972. Cation exchange selectivity in mica and vermiculite. Am. Mineral. 57, 1823-1831.

Earle, S., 2015. Physical geology. BCcampus, Victoria, B.C.

Elbra, T., Karlqvist, R., Lassila, I., Hæggström, E., Pesonen, L.J., 2011. Laboratory measurements of the seismic velocities and other petrophysical properties of the Outokumpu deep drill core samples, eastern Finland. Geophys. J. Int. 184, 405-415. https://doi.org/10.1111/j.1365-246X.2010.04845.x

El-Kaliouby, H., 2019. Groundwater prospecting in a hard-rock coastal area using off-set TDEM method: Case study, in: SEG Technical Program Expanded Abstracts 2019. Presented at the SEG Technical Program Expanded Abstracts 2019, Society of Exploration Geophysicists, San Antonio, Texas, pp. 2755-2758. https://doi.org/10.1190/segam2019-3209246.1

Ellis, D.V., Singer, J.M., 2007. Well logging for earth scientists, 2nd ed. Springer, Dordrecht, The Netherlands.

Flinchum, B.A., Holbrook, W.S., Grana, D., Parsekian, A.D., Carr, B.J., Hayes, J.L., Jiao, J., 2018. Estimating the water holding capacity of the critical zone using near-surface geophysics. Hydrol. Process. 32, 3308-3326. https://doi.org/10.1002/hyp.13260

Flinchum, B.A., Holbrook, W.S., Parsekian, A.D., Carr, B.J., 2019. Characterizing the critical zone using borehole and surface nuclear magnetic resonance. Vadose Zone J. 18, 1-18. https://doi.org/10.2136/vzj2018.12.0209 
1029 Pointer, D., 2019. Verification and validation and uncertainty quantification, in: Thermal Hydraulics

1030 Aspects of Liquid Metal Cooled Nuclear Reactors. Elsevier, pp. 383-405.

1031 https://doi.org/10.1016/B978-0-08-101980-1.00008-9

1032

Gleick, P.H., 1993. Water in Crisis: A Guide to the World's Fresh Water Resources, illustrated. ed.

1033 Oxford University Press.

1034

Glover, P., 2009. What is the cementation exponent? A new interpretation. Lead. Edge 28, 82-85.

1035 https://doi.org/10.1190/1.3064150

1036

He, R., Ma, H., Hafiz, R.B., Fu, C., Jin, X., He, J., 2018. Determining porosity and pore network

1037 connectivity of cement-based materials by a modified non-contact electrical resistivity measurement: Experiment and theory. Mater. Des. 156, 82-92. https://doi.org/10.1016/j.matdes.2018.06.045

Johnson, G.R., 1983. Rock property measurements and analysis of selected igneous, sedimentary, and metamorphic rocks from worldwide localities (Report No. 83-736), Open-File Report.

1041 https://doi.org/10.3133/ofr83736

1042 Jørgensen, S.E., Fath, B.D., 2011. Concepts of Modelling, in: Developments in Environmental 1043 Modelling. Elsevier, pp. 19-93. https://doi.org/10.1016/B978-0-444-53567-2.00002-8

1044 Kazakis, N., Vargemezis, G., Voudouris, K.S., 2016. Estimation of hydraulic parameters in a complex 1045 porous aquifer system using geoelectrical methods. Sci. Total Environ. 550, 742-750.

1046 https://doi.org/10.1016/j.scitotenv.2016.01.133

1047 Kirlas, M.C., Katsifarakis, K.L., 2020. Evaluation of automated groundwater level measurements for 1048 transmissivity and storativity calculation. J. Water Supply Res. Technol.-Aqua. https://doi.org/10.2166/aqua.2020.100

Kirsch, R., 2009. Groundwater geophysics: a tool for hydrogeology, 2nd ed. Springer, Berlin, Heidelberg. 
Krásný, J., Sharp, J.M., 2007. Hydrogeology of fractured rocks from particular fractures to regional approaches: State-of-the-art and future challenges, in: Groundwater in Fractured Rocks. CRC Press, pp. $1-30$.

Krásný, J., Sharp, J.M., Troeger, U., 2014. IAH Commission on Hardrock Hydrogeology (HyRoC): Past and present activities, future possibilities, in: Fractured Rock Hydrogeology, Selected Papaers in Hydrogeology. CRC Press, The Netherlands, pp. 1-12.

Kumar, D., Mondal, S., Nandan, M.J., Harini, P., Sekhar, B.M.V.S., Sen, M.K., 2016. Twodimensional electrical resistivity tomography (ERT) and time-domain-induced polarization (TDIP) study in hard rock for groundwater investigation: a case study at Choutuppal Telangana, India. Arab. J. Geosci. 9, 355. https://doi.org/10.1007/s12517-016-2382-1

Lachassagne, P., 2008. Overview of the hydrogeology of hard rock aquifers: applications for their survey, management, modelling and protection, in: Ahmed, S., Jayakumar, R., Salih, A. (Eds.), Groundwater dynamics in hard rock aquifers: sustainable management and optimal monitoring Network Design. Springer, Dordrecht, The Netherlands, pp. 40-63. https://doi.org/10.1007/978-1$4020-6540-8 \_3$

Lachassagne, P., Dewandel, B., Wyns, R., 2014. The conceptual model of weathered hard rock aquifers and its practical applications, in: Sharp, J.M. (Ed.), Fractured Rock Hydrogeology, Selected Papers in Hydrogeology. CRC Press, Taylor and Francis Group, The Netherlands, pp. 13-46. https://doi.org/10.1201/b17016-3

Lachassagne, P., Wyns, R., Bérard, P., Bruel, T., Chéry, L., Coutand, T., Desprats, J.-F., Le Strat, P., 2001. Exploitation of high-yields in hard-rock aquifers: downscaling methodology combining GIS and multicriteria analysis to delineate field prospecting zones. Groundwater 39, 568-581. https://doi.org/10.1111/j.1745-6584.2001.tb02345.x

Lachassagne, P., Wyns, R., Dewandel, B., 2011. The fracture permeability of Hard Rock Aquifers is due neither to tectonics, nor to unloading, but to weathering processes: Weathering and permeability of Hard Rock Aquifers. Terra Nova 23, 145-161. https://doi.org/10.1111/j.1365-3121.2011.00998.x 
Legchenko, A., Baltassat, J.-M., Beauce, A., Bernard, J., 2002. Nuclear magnetic resonance as a geophysical tool for hydrogeologists. J. Appl. Geophys. 50, 21-46. https://doi.org/10.1016/S09269851(02)00128-3

Legchenko, A., Comte, J.-C., Ofterdinger, U., Vouillamoz, J.-M., Lawson, F.M.A., Walsh, J., 2017. Joint use of singular value decomposition and Monte-Carlo simulation for estimating uncertainty in surface NMR inversion. J. Appl. Geophys. 144, 28-36. https://doi.org/10.1016/j.jappgeo.2017.06.010

Legchenko, A., Descloitres, M., Bost, A., Ruiz, L., Reddy, M., Girard, J.-F., Sekhar, M., Mohan Kumar, M.S., Braun, J.-J., 2006. Resolution of MRS applied to the characterization of hard-rock aquifers. Groundwater 44, 547-554. https://doi.org/10.1111/j.1745-6584.2006.00198.x

Legchenko, A., Descloitres, M., Vincent, C., Guyard, H., Garambois, S., Chalikakis, K., Ezersky, M., 2011. Three-dimensional magnetic resonance imaging for groundwater. New J. Phys. 13, 025022. https://doi.org/10.1088/1367-2630/13/2/025022

Leopold, M., Völkel, J., Huber, J., Dethier, D., 2013. Subsurface architecture of the Boulder Creek Critical Zone Observatory from electrical resistivity tomography. Earth Surf. Process. Landf. 38, 1417-1431. https://doi.org/10.1002/esp.3420

MacDonald, A.M., Davies, J., 2000. A brief review of groundwater for rural water supply in subSaharan Africa (Technical Report No. WC/00/33). BGS.

Massuel, S., Favreau, G., Descloitres, M., Le Troquer, Y., Albouy, Y., Cappelaere, B., 2006. Deep infiltration through a sandy alluvial fan in semiarid Niger inferred from electrical conductivity survey, vadose zone chemistry and hydrological modelling. CATENA 67, 105-118. https://doi.org/10.1016/j.catena.2006.02.009

Meunier, A., 2005. Clays. Springer, Berlin, Heidelberg.

Moe, H., Craig, M., Daly, D., 2010. Poorly productive aquifers summary report. CDM and the Environmental Protection Agency, Dublin. 
Moreno-Maroto, J.M., Alonso-Azcárate, J., 2018. What is clay? A new definition of "clay" based on 1103 plasticity and its impact on the most widespread soil classification systems. Appl. Clay Sci. 161, 571104 63. https://doi.org/10.1016/j.clay.2018.04.011

1105 Ofterdinger, U., Macdonald, A., Comte, J.-C., Young, M., 2019. Groundwater in fractured bedrock 1106 environments: managing catchment and subsurface resources. Geol. Soc. Lond. Spec. Publ. 479, 1107 SP479-2018. https://doi.org/10.1144/SP479-2018-170

Oldenburg, D.W., Li, Y., 1999. Estimating depth of investigation in dc resistivity and IP surveys. Geophysics 64, 403-416. https://doi.org/10.1190/1.1444545

Paillet, F.L., Reese, R.S., 2000. Integrating borehole logs and aquifer tests in aquifer characterization. Groundwater 38, 713-725. https://doi.org/10.1111/j.1745-6584.2000.tb02707.x

Palacky, G.J., 1988. Resistivity characteristics of geologic targets, in: Electromagnetic Methods in Applied Geophysics: Volume 1, Theory, Investigations in Geophysics. Society of Exploration Geophysicists, pp. 52-129. https://doi.org/10.1190/1.9781560802631.ch3

Pellerin, L., 2002. Applications of electrical and electromagnetic methods for environmental and geotechnical investigations. Surv. Geophys. 32.

1117 Piedrahita, J., Aguilera, R., 2017. A petrophysical dual-porosity model for evaluation of secondary 1118 mineralization and tortuosity in naturally fractured reservoirs. SPE-180242-PA 20, 304-316.

1119 https://doi.org/10.2118/180242-PA

1120 Pisani, L., 2011. Simple expression for the tortuosity of porous media. Transp. Porous Media 88, 1931121 203. https://doi.org/10.1007/s11242-011-9734-9

1122 Pongmanda, S., Suprapti, A., 2020. Performing application of cooper-jacob method for identification 1123 of storativity. IOP Conf. Ser. Earth Environ. Sci. 419, 012128. https://doi.org/10.1088/1755$1315 / 419 / 1 / 012128$ 
Revil, A., Cathles III, L.M., Losh, S., Nunn, J.A., 1998. Electrical conductivity in shaly sands with

1126 geophysical applications. J. Geophys. Res. Solid Earth 103, 23925-23936.

1127 https://doi.org/10.1029/98JB02125

1128 Revil, A., Qi, Y., Ghorbani, A., Coperey, A., Ahmed, A.S., Finizola, A., Ricci, T., 2019. Induced

1129 polarization of volcanic rocks. 3. Imaging clay cap properties in geothermal fields. Geophys. J. Int.

1130

218, 1398-1427. https://doi.org/10.1093/gji/ggz207

1131

Robert, T., Caterina, D., Deceuster, J., Kaufmann, O., Nguyen, F., 2012. A salt tracer test monitored

1132

with surface ERT to detect preferential flow and transport paths in fractured/karstified limestones.

1133

Geophysics 77, B55-B67. https://doi.org/10.1190/geo2011-0313.1

1134

Rubin, Y., Hubbard, S.S., 2005. Hydrogeophysics, Water science and technology library. Springer,

Dordrecht, The Netherlands.

1136

Salem, H.S., 2001. Determination of porosity, formation resistivity factor, archie cementation factor, and pore geometry factor for a glacial aquifer. Energy Sources 23, 589-596.

1138

https://doi.org/10.1080/00908310152125238

1139 Salem, H.S., Chilingarian, G.V., 1999. The cementation factor of Archie's equation for shaly

1140 sandstone reservoirs. J. Pet. Sci. Eng. 23, 83-93. https://doi.org/10.1016/S0920-4105(99)00009-1

1141 Schön, J.H., 2015. Density, in: Developments in Petroleum Science. Elsevier, pp. 109-118.

1142 https://doi.org/10.1016/B978-0-08-100404-3.00004-4

1143 Sharma, P.V., 1997. Environmental and Engineering Geophysics. Cambridge University Press,

1144 Cambridge. https://doi.org/10.1017/CBO9781139171168

1145 Singhal, B.B.S., 2008. Nature of hard rock aquifers: hydrogeological uncertainties and ambiguities,

1146 in: Ahmed, S., Jayakumar, R., Salih, A. (Eds.), Groundwater Dynamics in Hard Rock Aquifers:

1147 Sustainable Management and Optimal Monitoring Network Design. Springer, Dordrecht, The

1148 Netherlands, pp. 20-39. https://doi.org/10.1007/978-1-4020-6540-8_2 
Singhal, B.B.S., Gupta, R.P., 2010. Applied hydrogeology of fractured rocks, 2nd ed. Springer,

1150 Dordrecht, The Netherlands.

1151 Slater, L., 2007. Near surface electrical characterization of hydraulic conductivity: From

1152 Petrophysical Properties to Aquifer Geometries-A Review. Surv. Geophys. 28, 169-197.

1153 https://doi.org/10.1007/s10712-007-9022-y

1154 Tabibi, M., Emadi, M.A., 2013. Variable cementation factor determination (empirical methods).

1155 Presented at the SPE 13th Middle East Oil Show \& Conference, Bahrain, p. 9.

1156

https://doi.org/10.1117/12.486983

1157

Taylor, R.G., Scanlon, B., Döll, P., Rodell, M., van Beek, R., Wada, Y., Longuevergne, L., Leblanc,

1158

M., Famiglietti, J.S., Edmunds, M., Konikow, L., Green, T.R., Chen, J., Taniguchi, M., Bierkens,

M.F.P., MacDonald, A., Fan, Y., Maxwell, R.M., Yechieli, Y., Gurdak, J.J., Allen, D.M.,

1160 Shamsudduha, M., Hiscock, K., Yeh, P.J.-F., Holman, I., Treidel, H., 2013. Ground water and climate change. Nat. Clim. Change 3, 322-329. https://doi.org/10.1038/nclimate1744

Tiab, D., Donaldson, E.C., 2016. Porosity and permeability, in: Petrophysics. Elsevier, pp. 67-186. https://doi.org/10.1016/B978-0-12-803188-9.00003-6

1164

Tiab, D., Restrepo, D.P., Igbokoyi, A.O., 2006. Fracture porosity of naturally fractured reservoirs, in: SPE-104056-MS. Presented at the International Oil Conference and Exhibition in Mexico, Society of Petroleum Engineers, Cancun, Mexico, p. 13. https://doi.org/10.2118/104056-MS

Tokan-Lawal, A., Landry, C.J., Prodanovic, M., Eichhubl, P., 2014. Understanding tortuosity and permeability variations in naturally fractured reservoirs: Niobrara Formation, in: Proceedings of the 2nd Unconventional Resources Technology Conference. Presented at the Unconventional Resources Technology Conference, American Association of Petroleum Geologists, Denver, Colorado, USA.

1171 https://doi.org/10.15530/urtec-2014-1922870

1172 Turesson, A., 2006. Water content and porosity estimated from ground-penetrating radar and 1173 resistivity. J. Appl. Geophys. 58, 99-111. https://doi.org/10.1016/j.jappgeo.2005.04.004 
1174 Undul, O., Tugrul, A., Zarif, I., 2011. Identifying the weathering profiles of ultramafic rocks using 1175 electrical resistivity tomography (ERT), in: ARMA-11-172. Presented at the 45th U.S. Rock

1176 Mechanics / Geomechanics Symposium, American Rock Mechanics Association, ARMA, p. 10.

1177 Urish, D.W., 1981. Electrical resistivity-hydraulic conductivity relationships in glacial outwash 1178 aquifers. Water Resour. Res. 17, 1401-1408. https://doi.org/10.1029/WR017i005p01401

1179 Vereecken, H., 2006. Applied Hydrogeophysics, NATO science series. Springer, Dordrecht, The 1180 Netherlands.

1181 Vouillamoz, J.M., Sokheng, S., Bruyere, O., Caron, D., Arnout, L., 2012. Towards a better estimate of 1182 storage properties of aquifer with magnetic resonance sounding. J. Hydrol. 458-459, 51-58.

1183 https://doi.org/10.1016/j.jhydrol.2012.06.044

1184 Waxman, M.H., Smits, L.J.M., 1968. Electrical conductivities in oil-bearing shaly sands. Soc. Pet. 1185 Eng. J. 8, 107-122. https://doi.org/10.2118/1863-A

1186 Whitman, D., Yeboah-Forson, A., 2015. Electrical resistivity and porosity structure of the upper 1187 Biscayne Aquifer in Miami-Dade County, Florida. J. Hydrol. 531, 781-791.

1188 https://doi.org/10.1016/j.jhydrol.2015.10.049 